
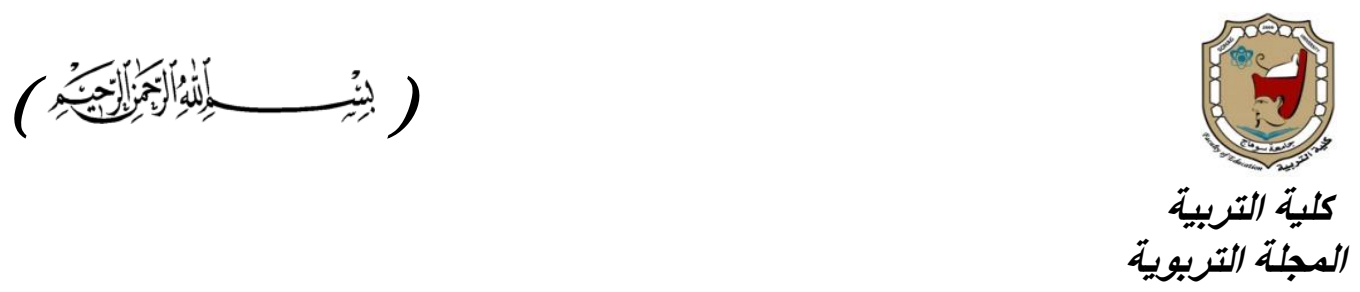

\title{
دور الأسرة في تنشئة أبنائها على الفكر الآمن
}

$$
\text { (إعداد }
$$

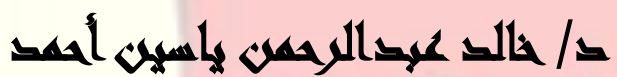

دكتوراه الفاسفة في التربية تغصص "أصول التربية" ومضو هيئة التلدريس بالازهر الشريف

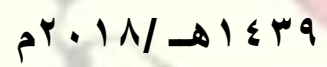

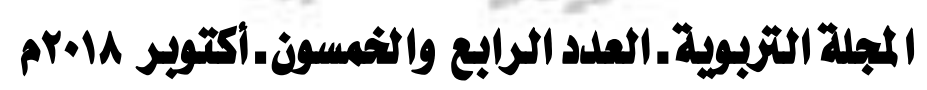

Print:(ISSN 1687-2649) Online:(ISSN 2536-9091) 


\title{
ملخص البجث
}

تمثل الأسرة المحضن الأول للأبناء، وهي بمثابة المدرسة الأولى التي تزود الأبناء أثناء

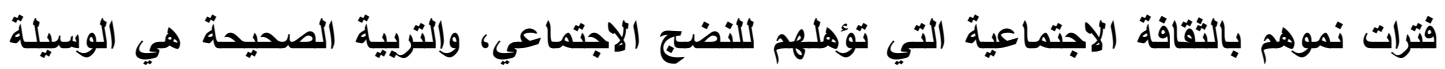

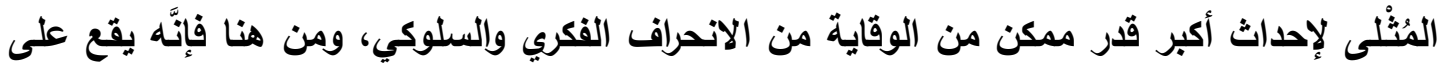

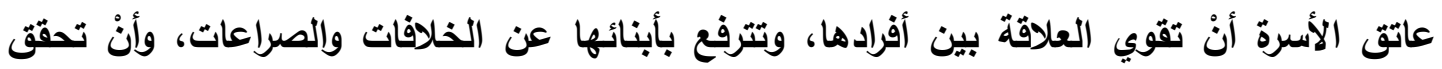

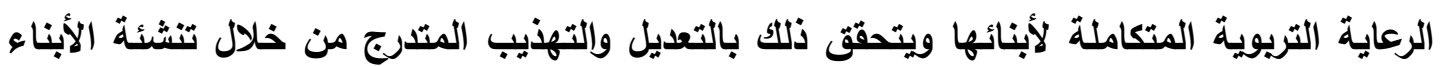

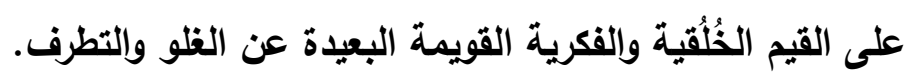

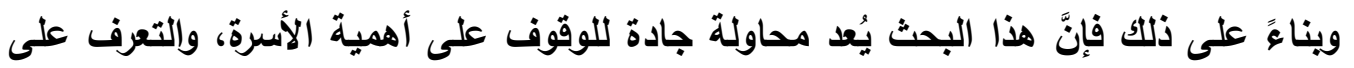

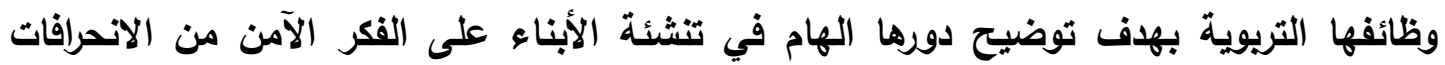

ويسعى البحث إلى تحقيق الأهداف التالية:

ا ـ التعرف على مفهوم الأسرة، وأهميتها.

r. r. r r التعرف الوظائف، والأهداف المتعددة للأسرة.

r. التعرف على دور الأسرة في تنثئة أبنائها على الفكر الآمن.

الكلمات المفتاحية: الأسرة - الفكر الآمن.

\begin{abstract}
The role of the family in Bringing up its children into Safe Thinking

The family considered the first and most important incubator for children. It works as the first school that provides children, during their periods of growth, with the social culture that prepares them for social maturity. The right education is the best way to prevent the intellectual and behavioral deviation. And it must achieve integrated educational care for its children, and this is achieved through gradual adjustment and improvement through the upbringing of children to the moral and intellectual values that keep them far
\end{abstract} away from extremism.

This research is a serious attempt to identify the importance of the family, and to identify its educational functions and then clarify its important role in raising and bringing up children to the correct and safety thinking from myths and misguidance and destructive deviations.

* The current research seeks to achieve the following objectives:

1. Understand the concept of the family, and its importance.

2. Identify the various functions and objectives of the family

3. Recognize the important role of the family in bringing up their children to safe thinking. 


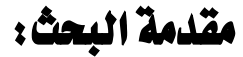

إنَّ سلامة المجتمع وقوة بنيانه ومدى تقدمه وازدهاره مرتبط بسلامة أفراده، فالقرد داخل

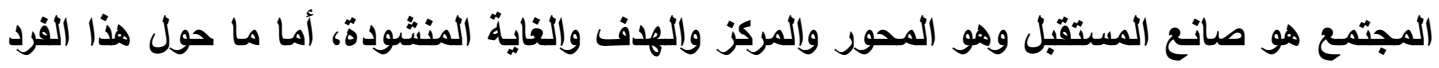

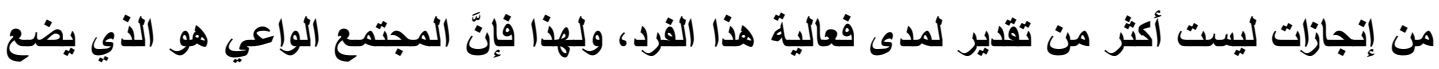

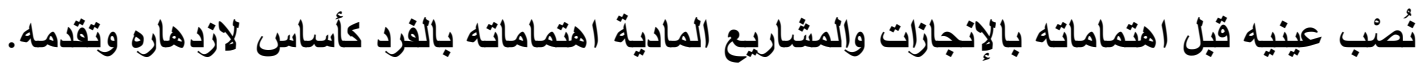

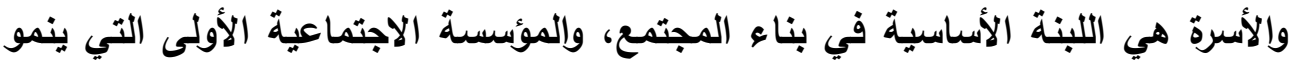

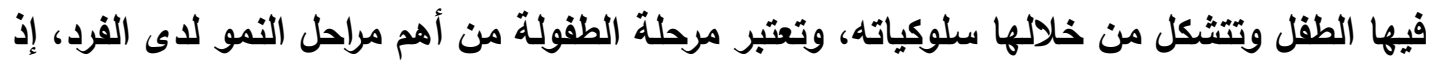

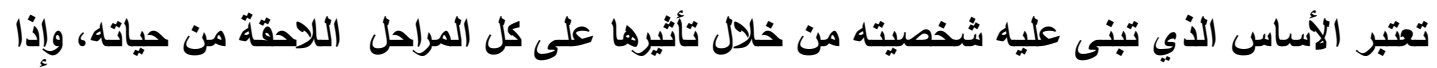
كان هذا البناء سليمًا يمكن للفرد أن يتوافق مع متطلبات الحياة الاجتماعية التفاعلية بمختلف

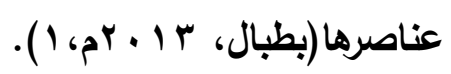
وتعد الأسرة شيء مهم للفرد، والدور الرئيس للأسرة هو الحب والرعاية للأبناء ومساعداتهم

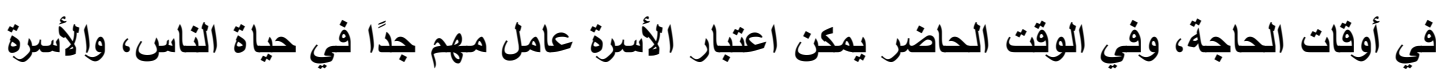
يمكن أنْ يُنْظَر إليها على أنَّها قلب وروح البشر (Defrain, John, et al, 2008).

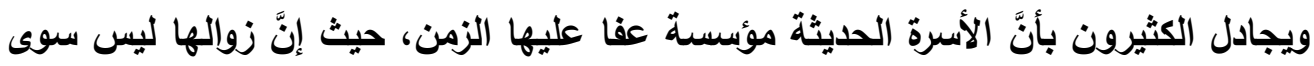

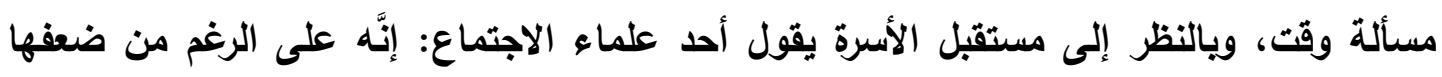

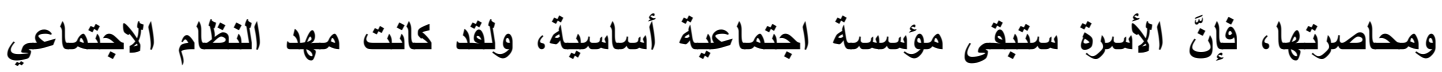
الحديث، وستبقى الأساس لأي مجتمع يهتم بالسعادة وإلحرية والمساواة والازدهار لجميع أعضائة العضائه

(Brigitte Berger,2002)

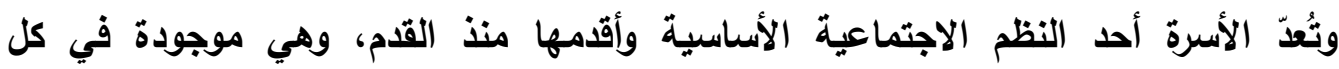

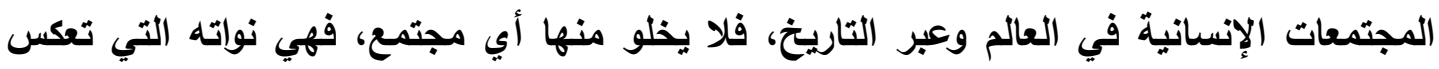

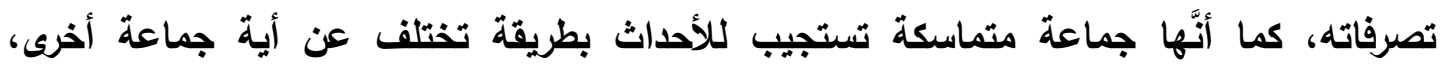

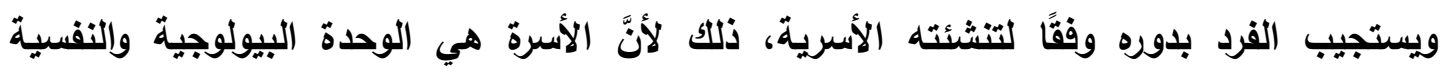

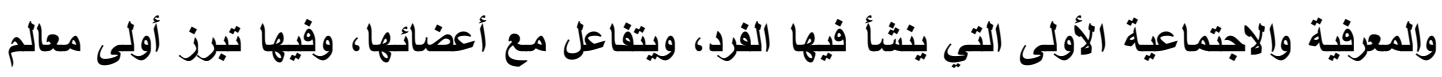

شخصيته في سنواته الأولى المبكرة (William M. Pinsof \& Jay L. Lebow,2005).

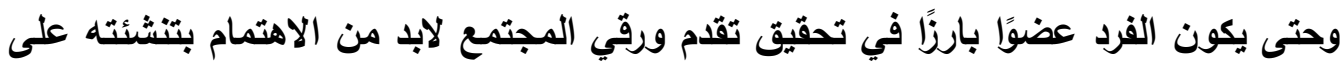

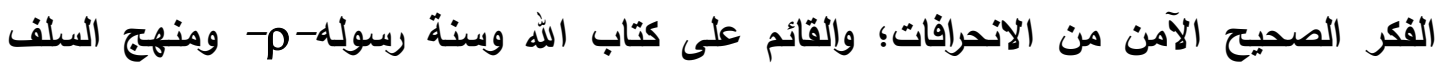

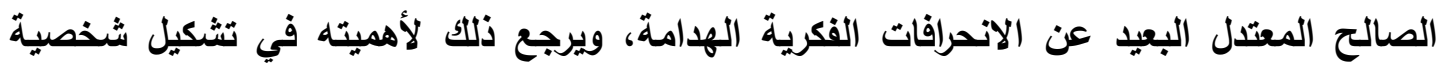

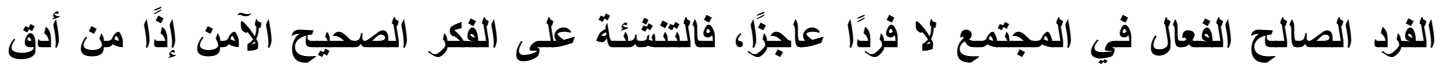

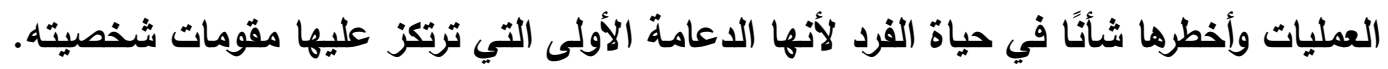


وتتشئة الأبناء على الفكر الآمن أو ما يسمى بالأمن الفكري يبدأ بالتفكير الناقد وإعمال

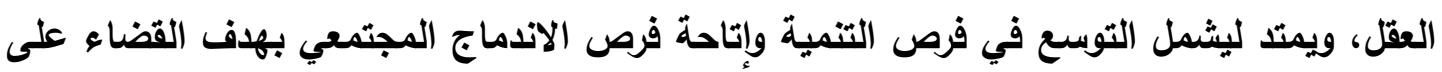

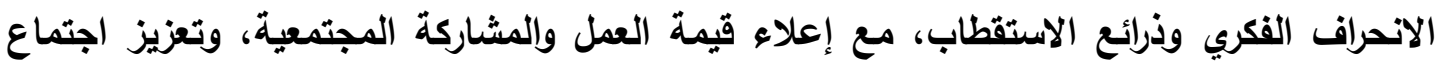

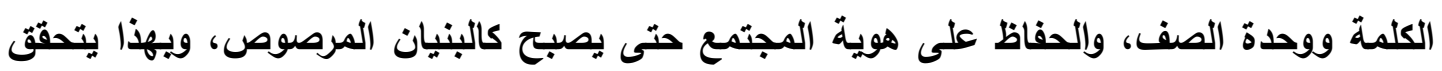

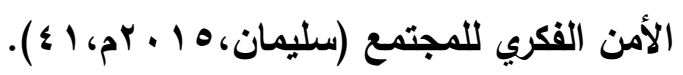
والتنشئة على الفكر الآمن البعيد عن الانحراف عملية مستمرة لا تقتصر فقط على مرحلة

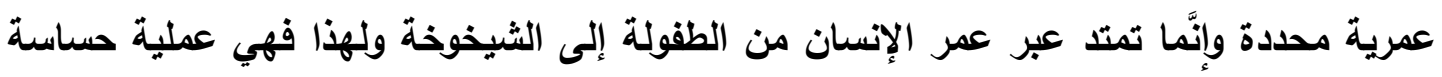

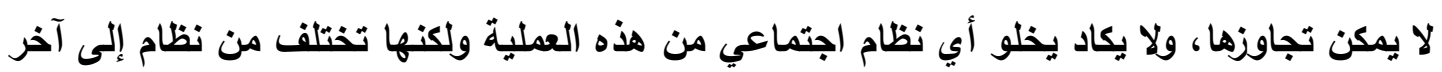

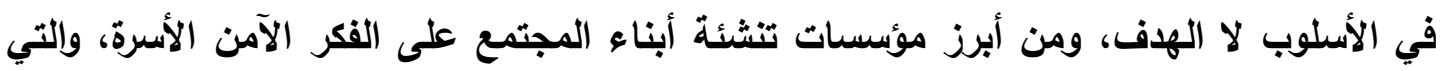

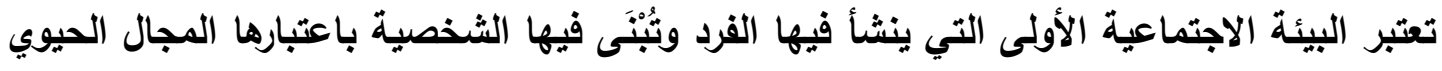

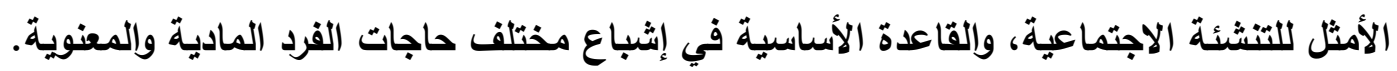

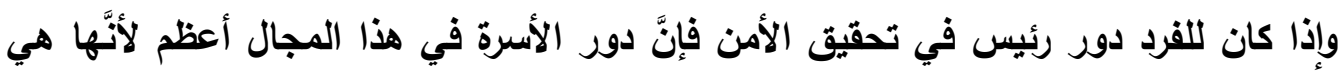

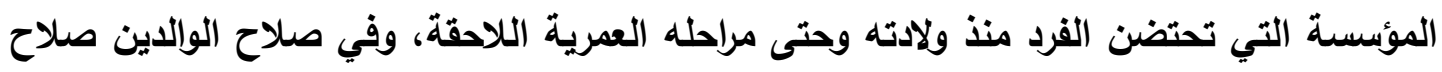

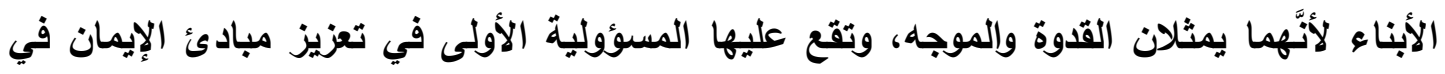

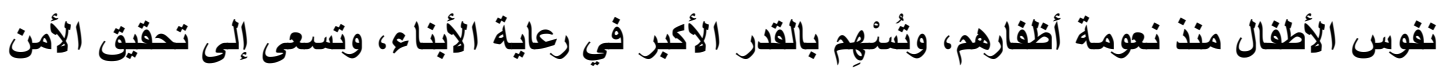

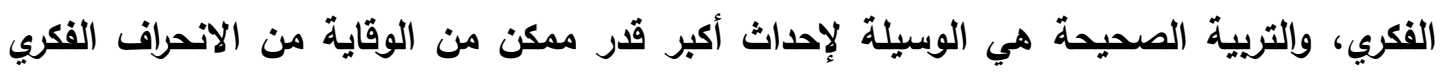

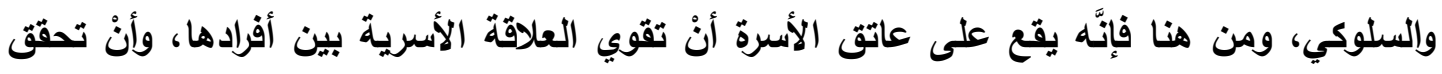

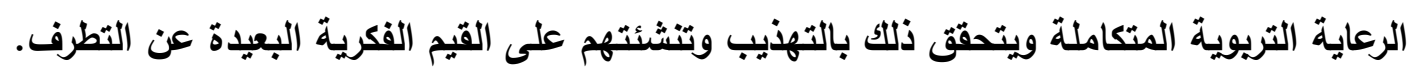

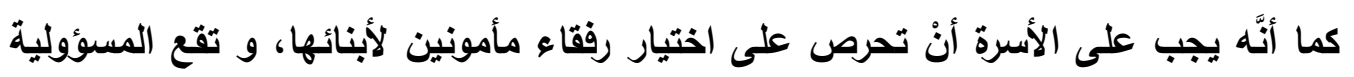

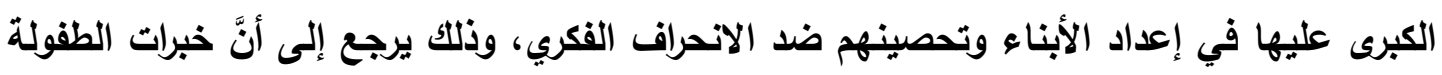

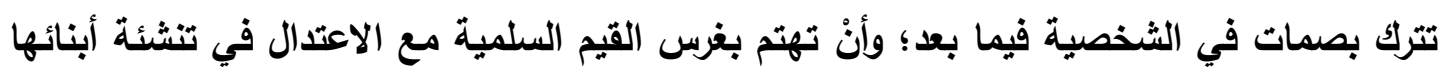
فلا إفراط في القسوة ولا تفريط في المناقثشة والحوار، والجلوس معهم ونصحهم للابتعاد عن الانحراف الفكري المضل.

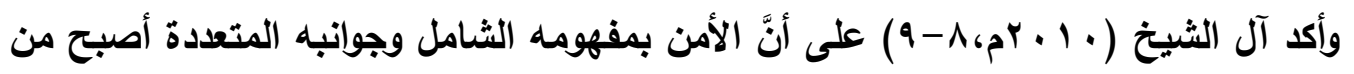

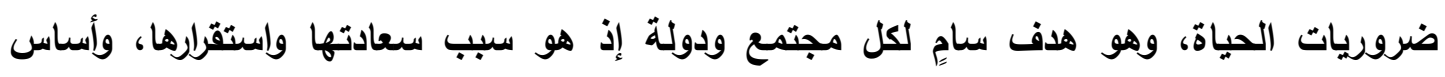

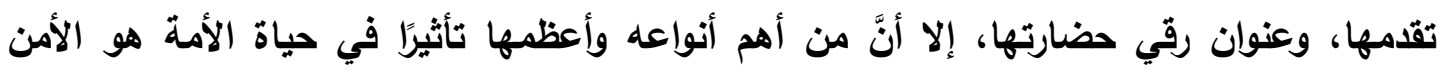

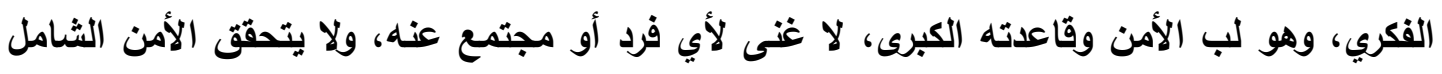

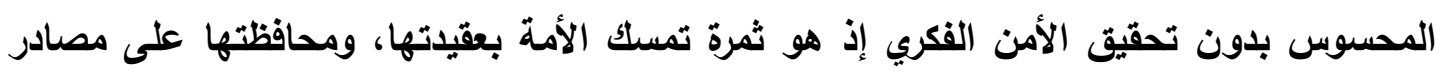
تثريعها وأخلاقها السامية ومُشُشها العليا. 


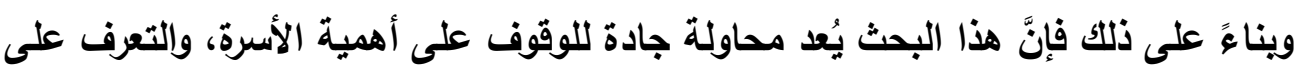

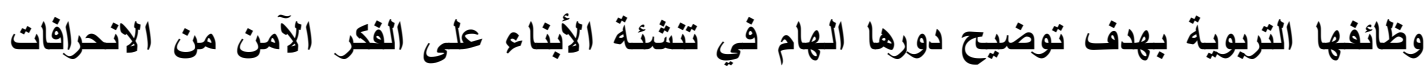
الفكرية الهدًّامة.

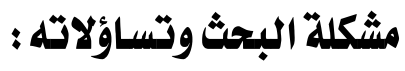

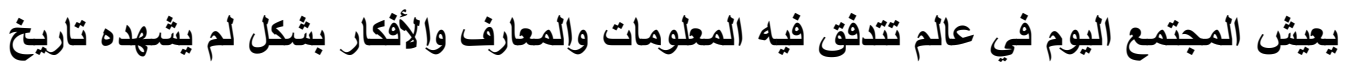

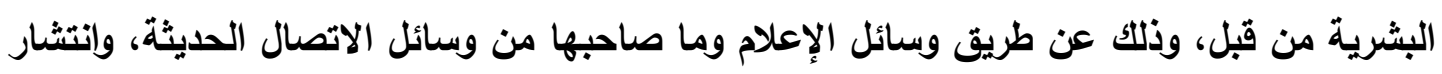

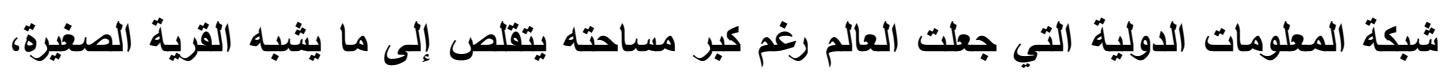

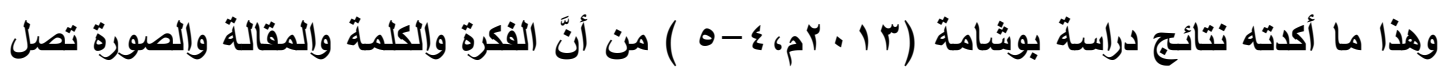

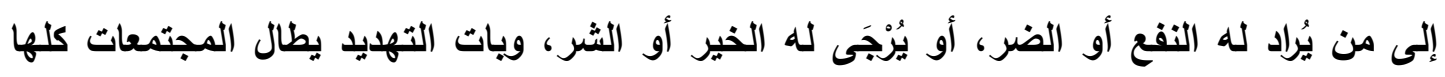
أفرادًا وجماعات، ويقتحم المؤسسات التعليمية والتريوية تحت شعت شعارات الثرات التعاون العلمي، والتبادل الثقافي وما أفرزه نظام العولمة.

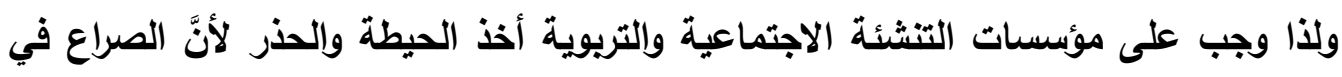

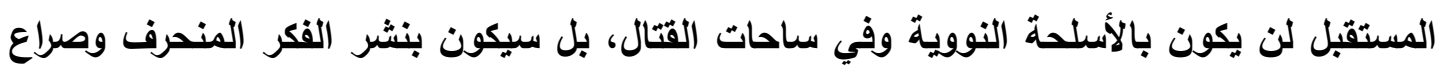

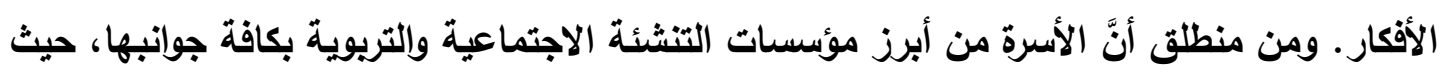

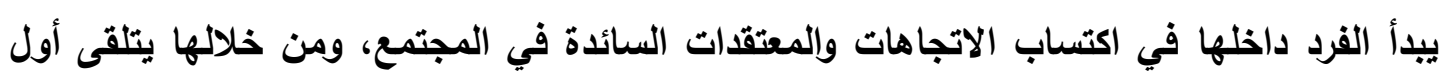

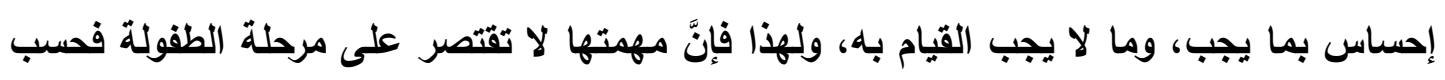

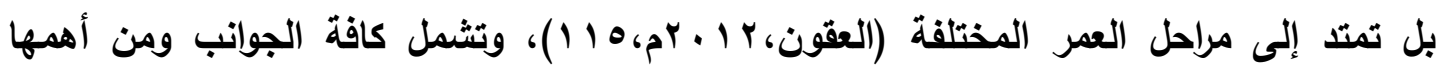
الجانب العقلي والفكري.

وتعيش الأسرة اليوم أزمات متعددة الأنواع، وهذا يتفق مع ما أثنارت إليه دراسة عودها

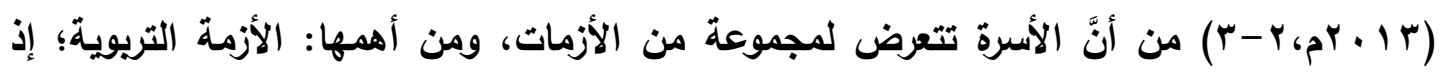

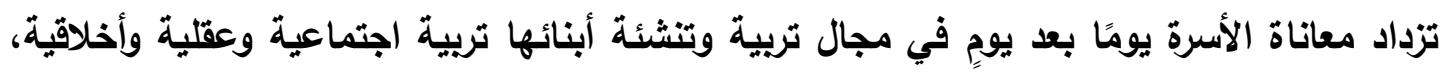

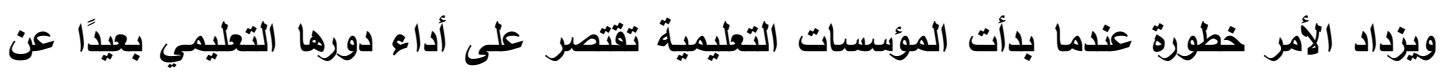

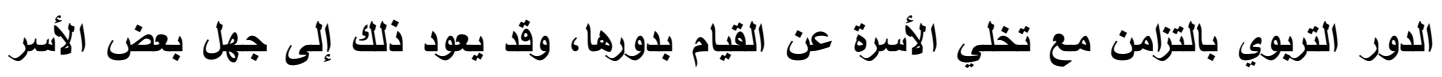

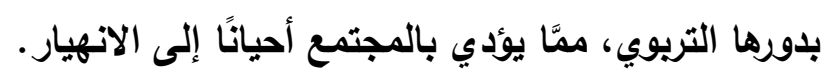

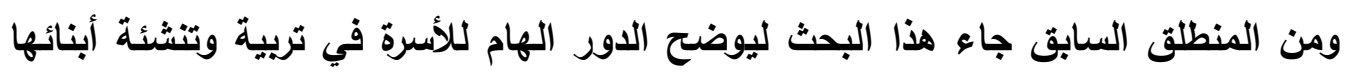

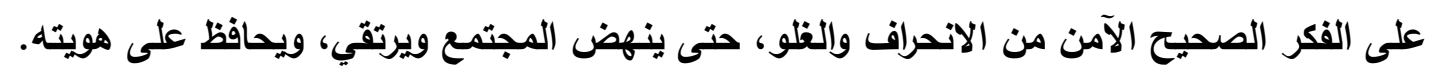

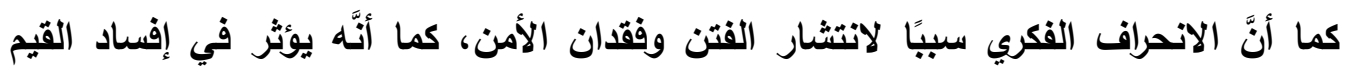

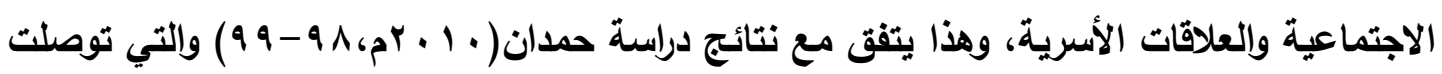
إلى أنَّ الانحراف الأسري يُضْعِف الروابط على مستوى الأسرة والمجتمع فتظهر النزاعات والتهوترات 
والصراعات، ويؤثثر تأثيرًا شديدًا في اقتصاد وتتمية المجتمع بما يحدثه من إتلاف للأموال والأنفس،

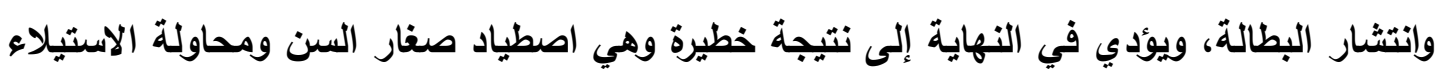
على عقولهم، وترسيخ الأفكار المنحرفة فيها.

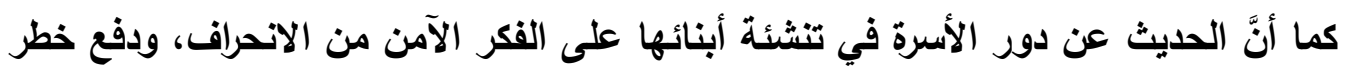

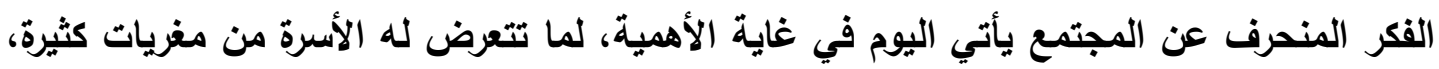

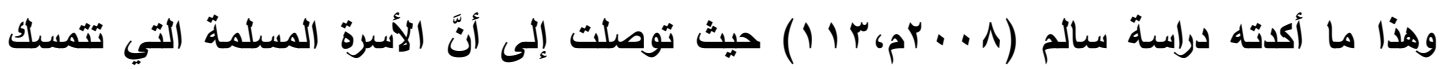

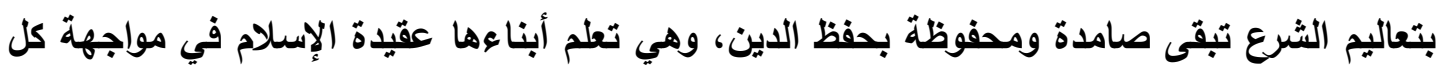

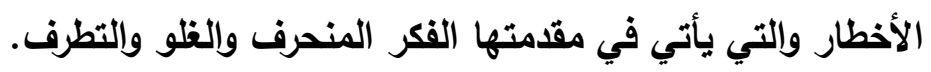

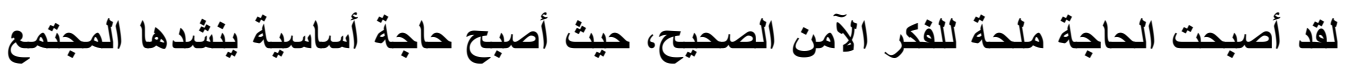

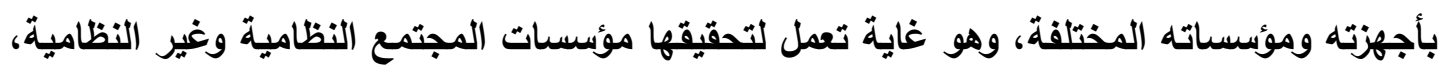

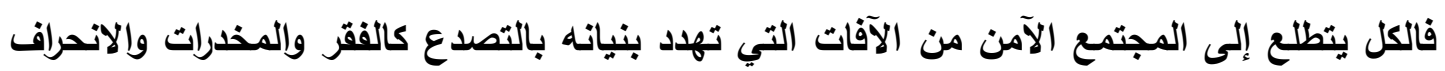

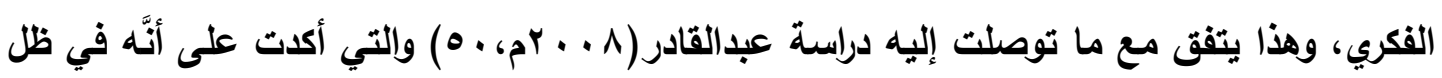

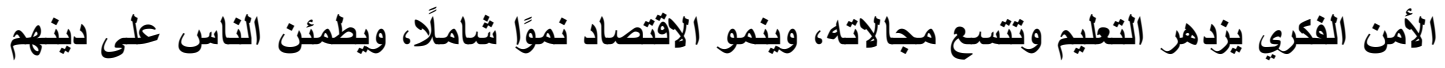

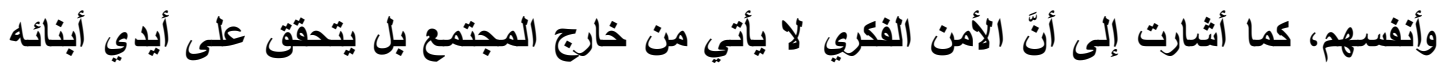

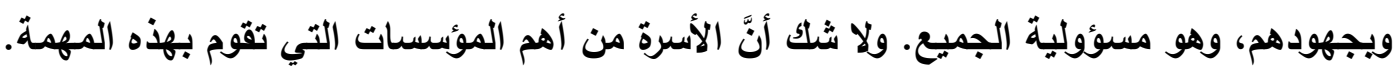

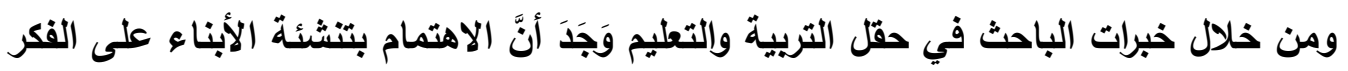

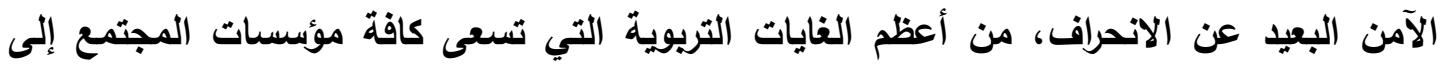

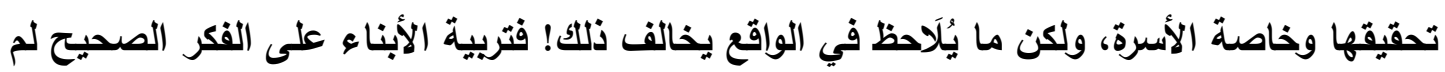

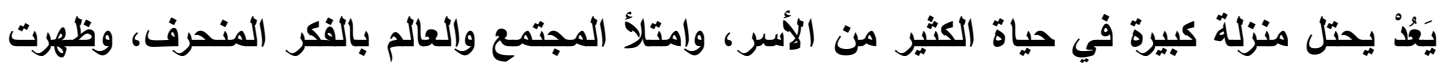

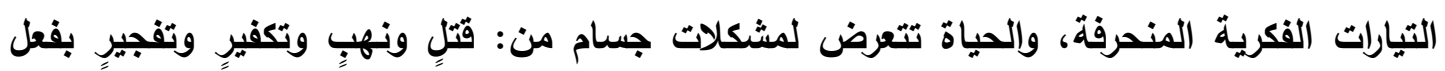

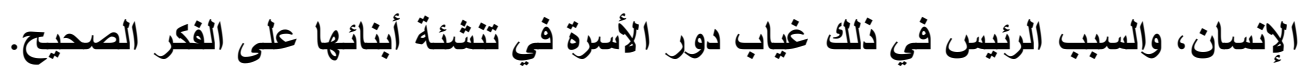

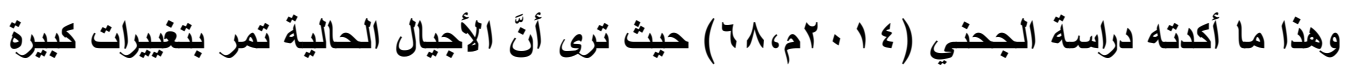

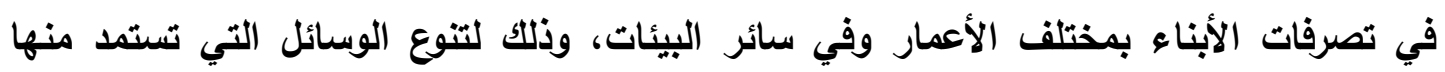

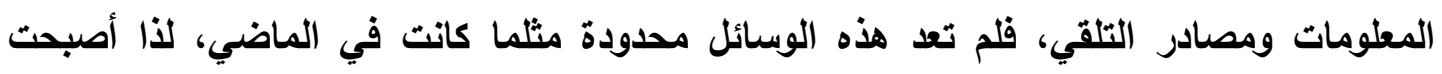
المسؤولية الملقاة على عاتق الأسرة أكبر ممَّا كانت في الأجيال السابقة.

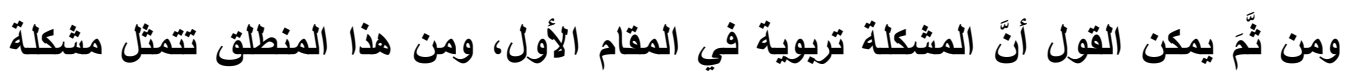

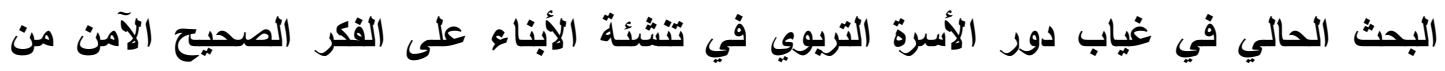

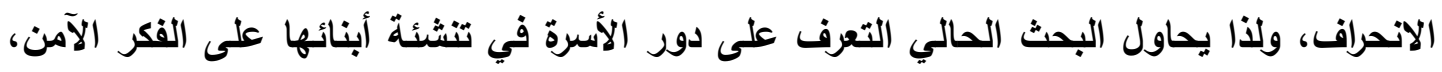

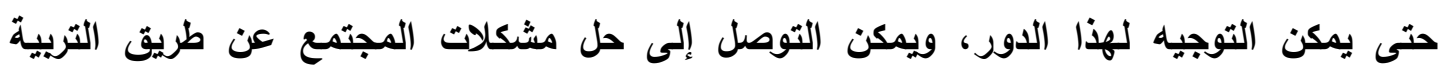


الصحيحة، وقد صاغها الباحث في التساؤل الرئيس التالي: كيف تُنْهِم الأسرة في تنشئة أبنائها على الفكر الصحيح الآمن؟ ويتفرع من هذا التساؤل التساؤلات الفرعية التالية:

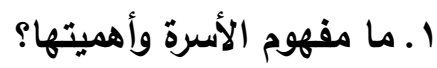

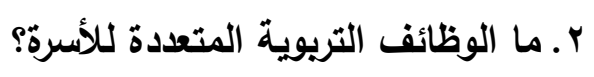

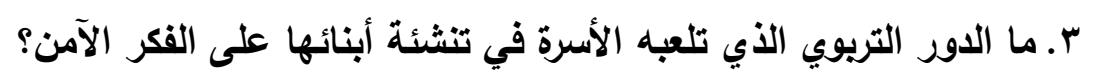

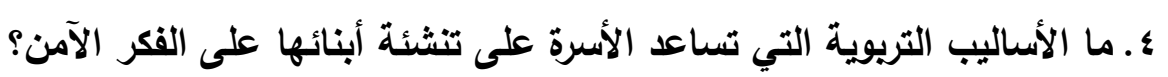

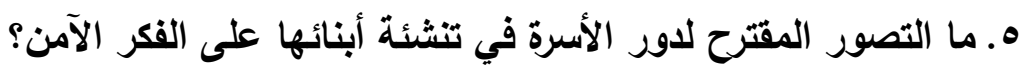

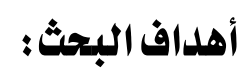
يهلفف البحث الحالي إلى وضع تصور مقترح لاور الأسرة في تنشئة أبنائها على الفكر

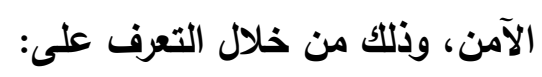

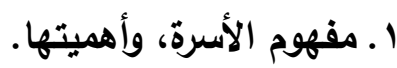
r. الوظائف التربوية للأسرة وتحديدها. r. بـ دور الأسرة في تنثئة أبنائها على الفكر الصحيح الآلمن. ؛. بعض الأساليب التريوية التي تساعد الأسرة في تنشئة أبنائها على الفكر الآمن. هـ التصور المقترح لاور الأسرة في تنشئة أبنائها على الفكر الآمن.

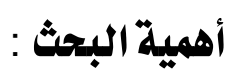

$$
\text { يمكن تحديد أهمية البحث فيما يلي: }
$$

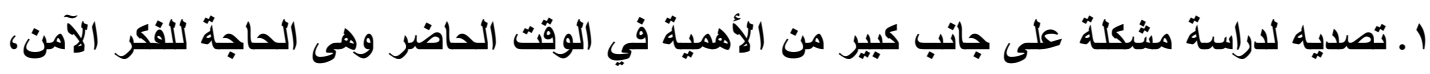

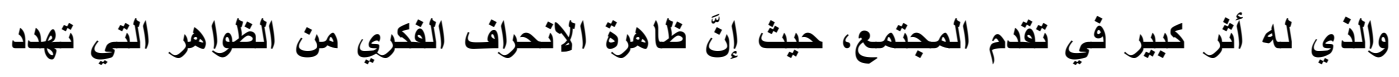

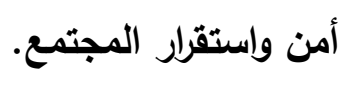

r. أنَّ هذا البحث محاولة للنهوض بدور الأسرة الهام لتصبح من المقومات الرئيسة في تطوير

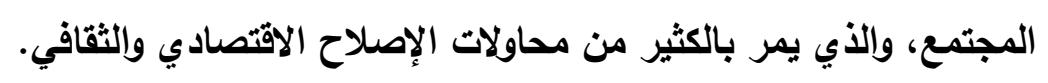

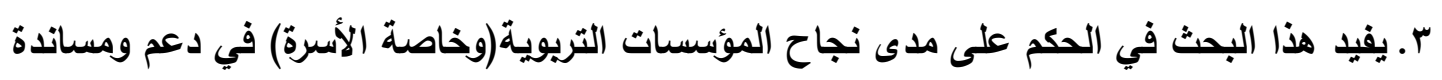
القضايا التي تخص المجتمع وتمس أمنه وسلامته.

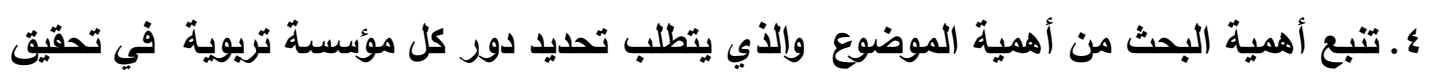

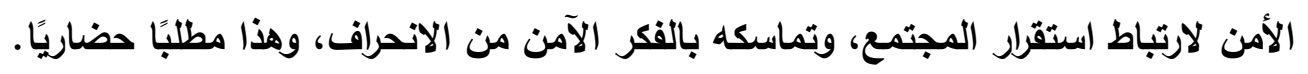

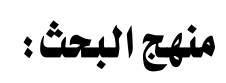
يعتمد البحث الحالي على المنهج "الوصفي"؛ لملائمته لأهداف البحث وطبيعته، ولكونه من

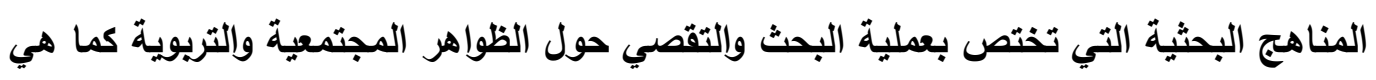


قائمة في الواقع، ثم وصفها وتثخيصها، وتحليلها، وتفسيرها بهدف اكتثاف العلاقات بينتها.

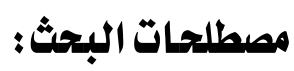

الأسرة:

الأسرة في اللغة هي أهل الرجل وعثيرته، وفى الاصطلاح هي الجماعة المعتبرة نواة

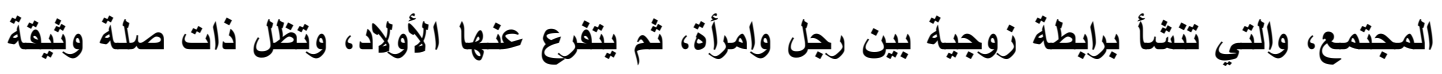

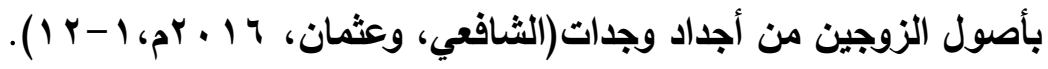

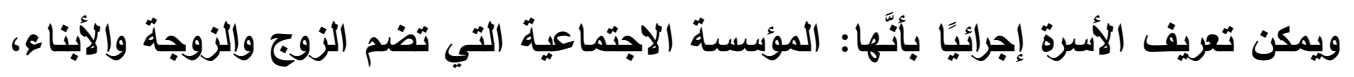

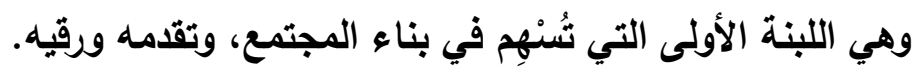
الفكر:

الفكر مخزون ذاكرة الإنسان من الثقافة، والقيم الاجتماعية، والمبادئ الأخلاقية التي يتعلمها من المجتمع الذي ينشأ ويعيش فيه. جاء في لسان العرب وتاج العروس الفكر والتفكير: إعمال الخاطر في الثيءو(ابن منظور،

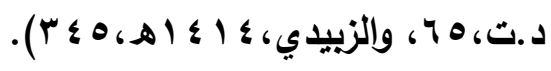

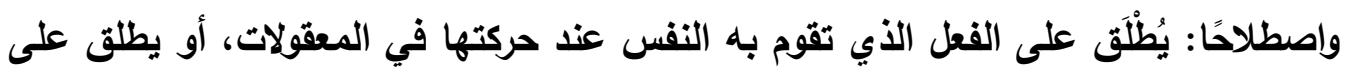

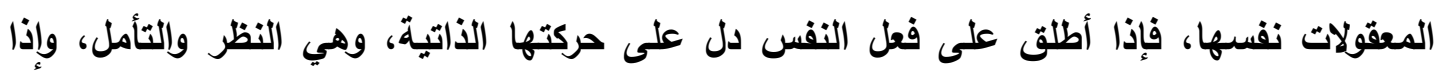

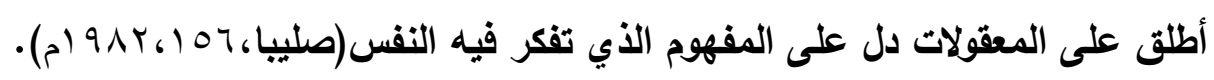

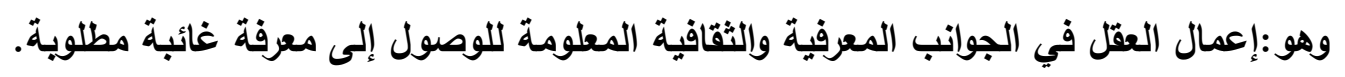
الفكر الآمن:

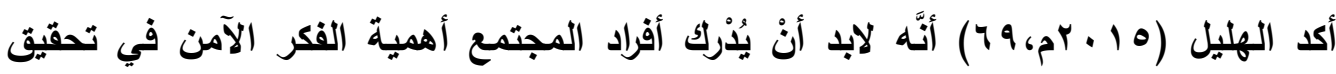

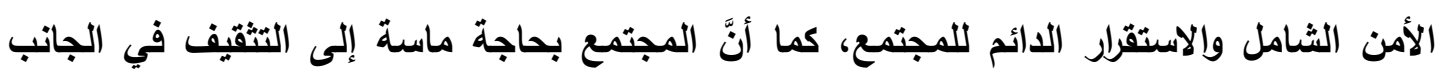

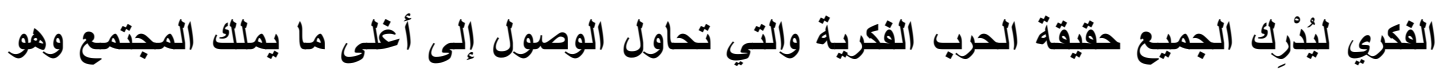
أبنائه، ومحاولة تثكيل فكرهم في ظل غياب دور الأسرة في مواجهة الحرب الفكرية.

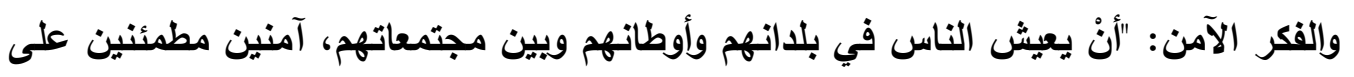

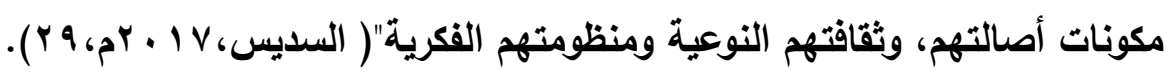

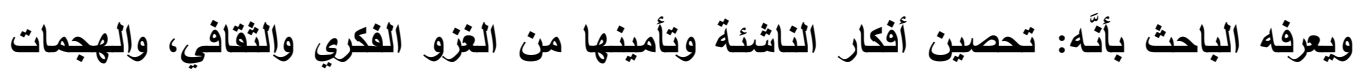

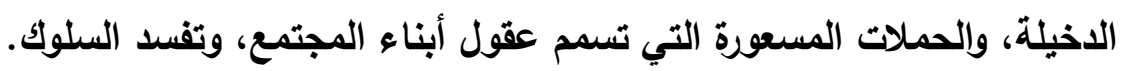




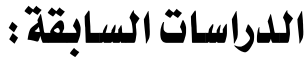

يعرض الباحث لبعض الدراسات السابقة ذات العلاقة بموضوع البحث الحالي كالتالي:

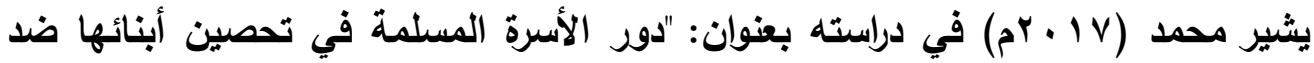
الإرهاب والتطرف من منظور التربية الإسلامية" إلى إلقاء الضوء على الدور التريوي للأسرة المسلمة

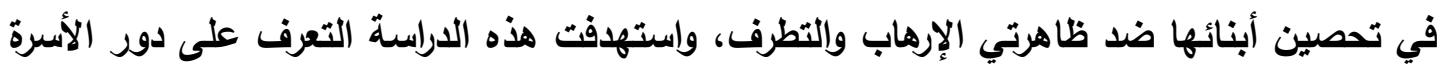

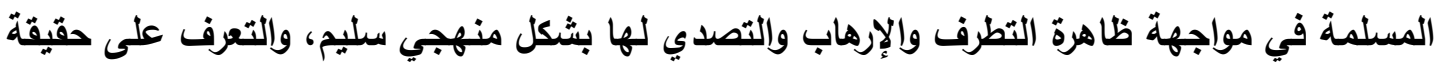

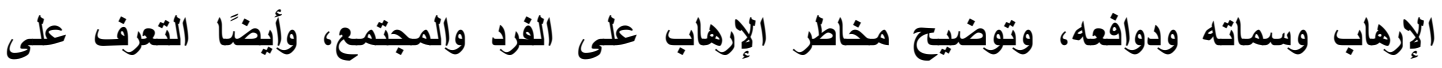

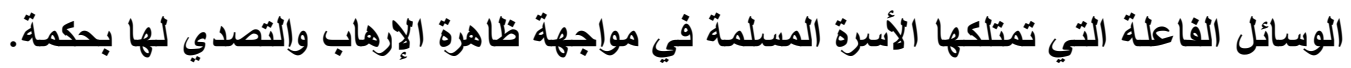

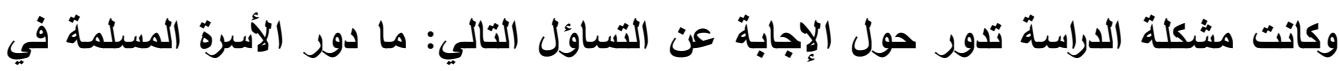

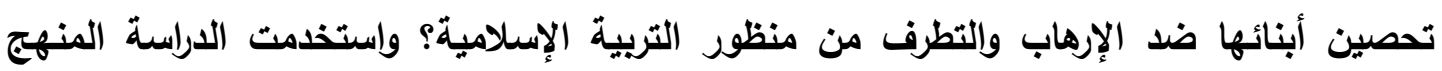
الوصفي. وتناولت نظمى (10 ب rم) في دراستها بعنوان: "دور الأسرة في تفعيل الوسطية لبناء المناعة

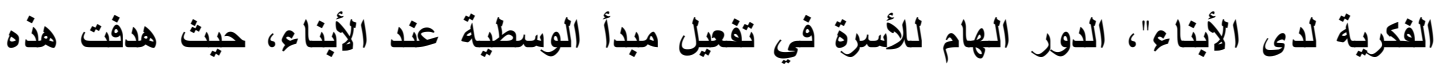

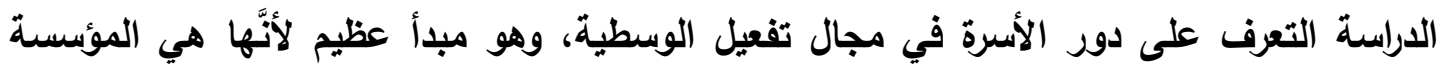

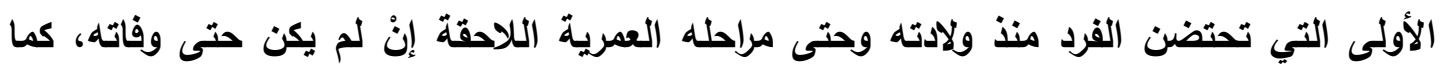

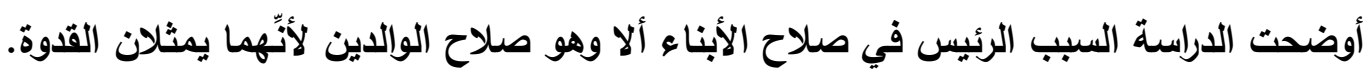

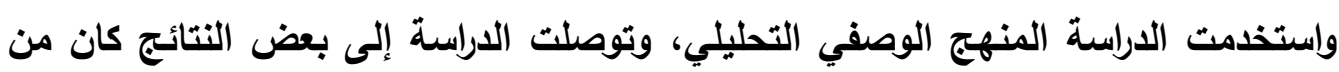

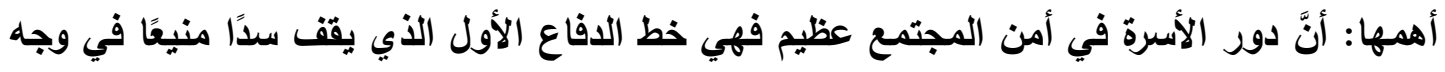

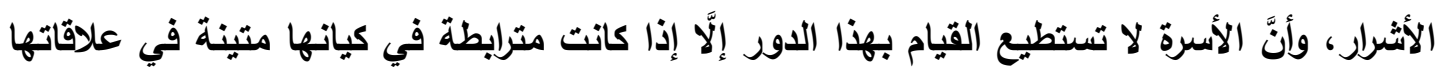

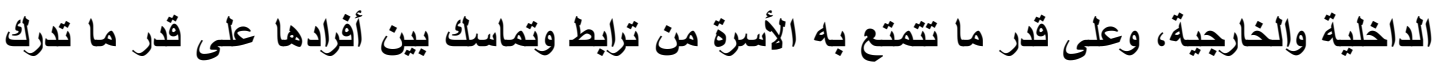

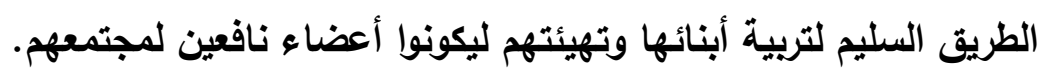

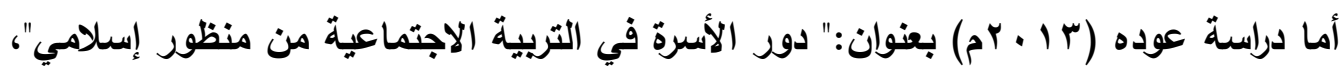

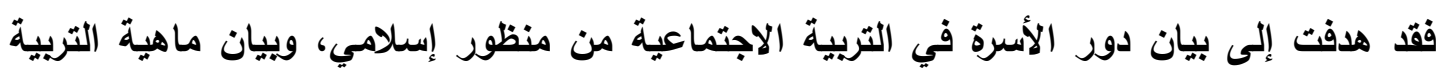

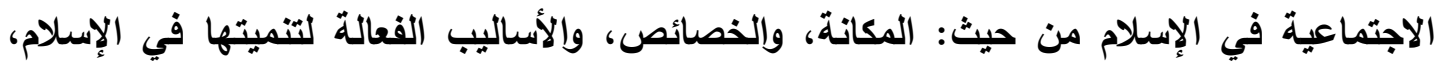

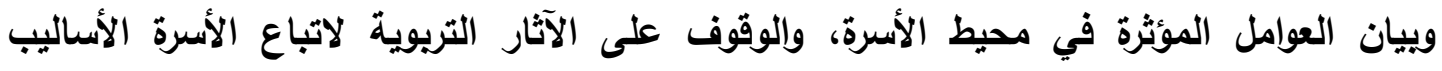
الإسلامية في التربية الاجتماعية.

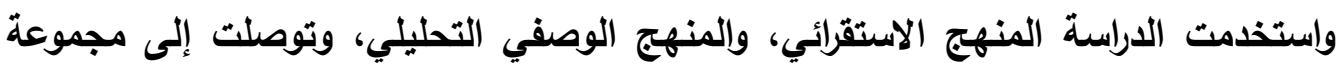

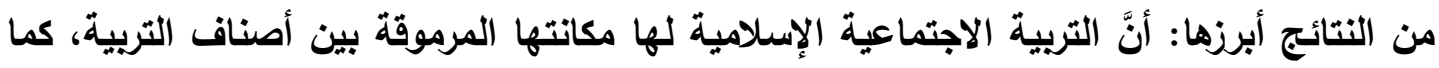

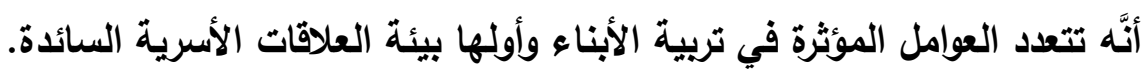




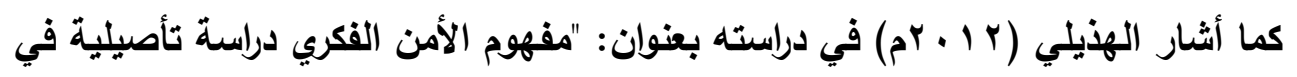

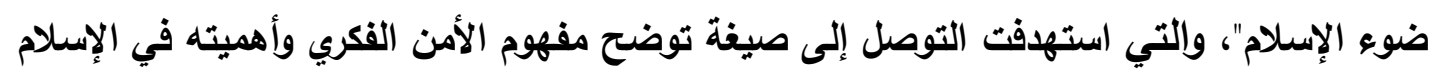

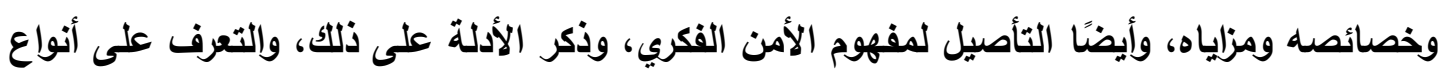

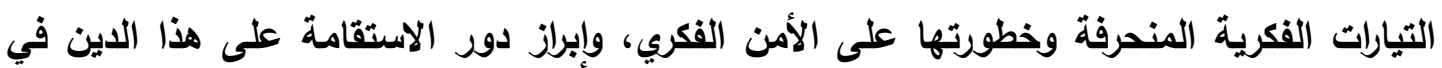
تعزيز الأمن الفكري واستقراره. واستخدت الدراسة المنهج التكاملي المشتمل على عدد من المناهج البحثية، ومن أهم تلكى

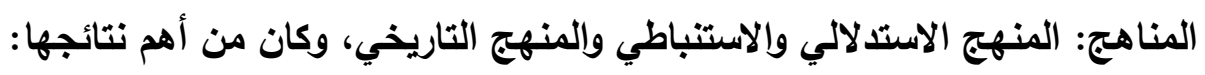

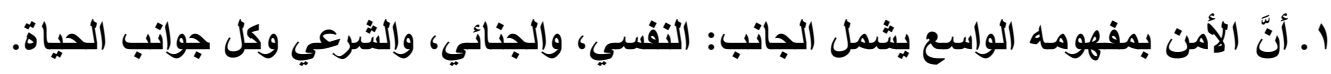

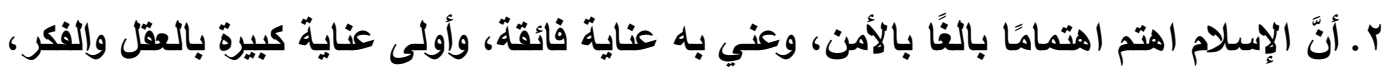

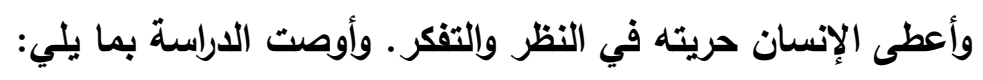

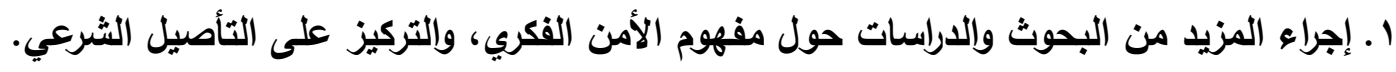

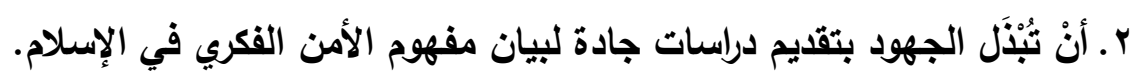

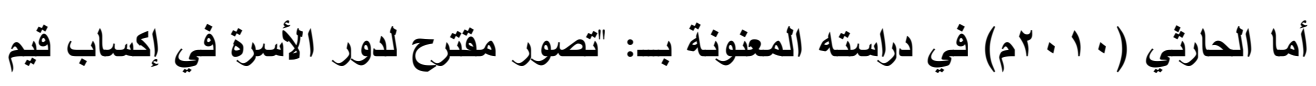

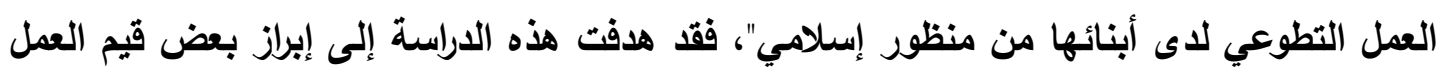

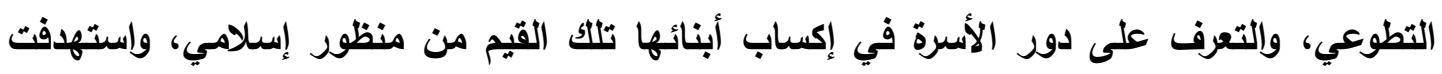
أيضًا الإجابة عن العديد من التساؤلات من أههـا:

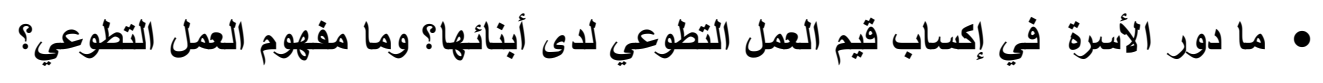

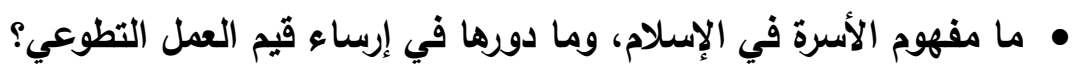

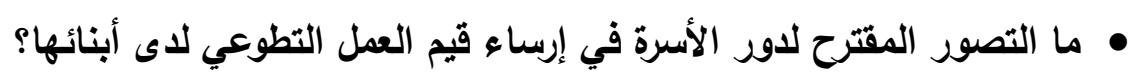

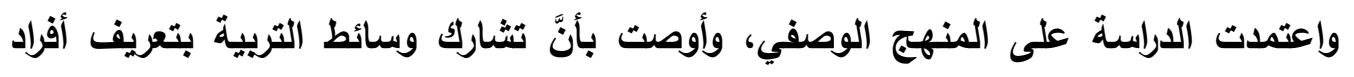

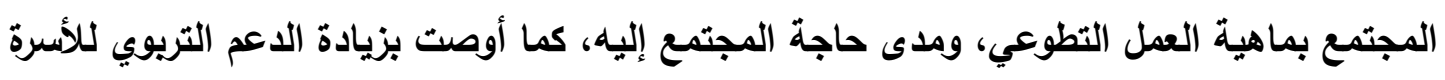

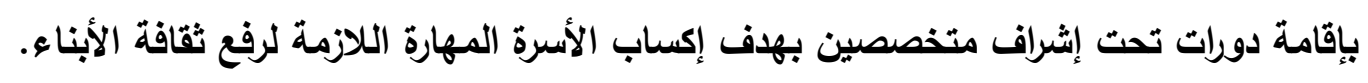

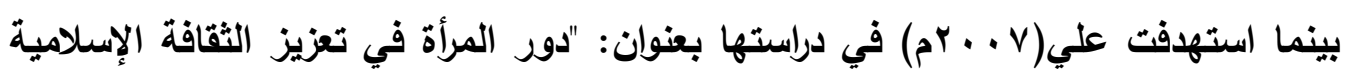

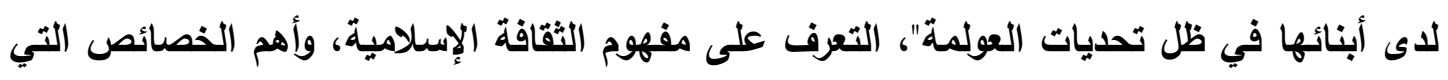

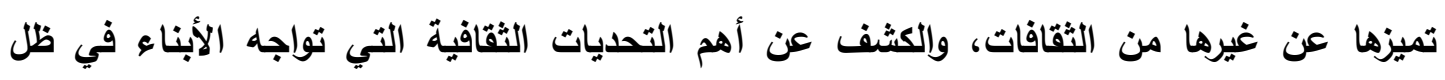

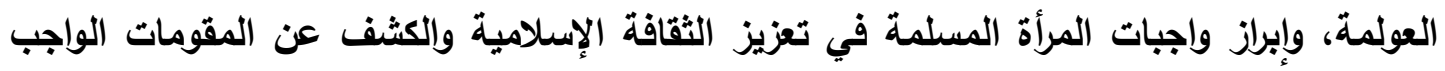

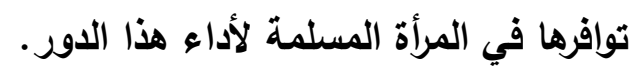
واستخذت الدراسة المنهج الوصفي التحليلي، وأوصت بما يلي: 
• لا بد من وقفة متأنية صادقة وملحة من جميع المخلصين لإعداد برامج ثقافية تحدد الهوية

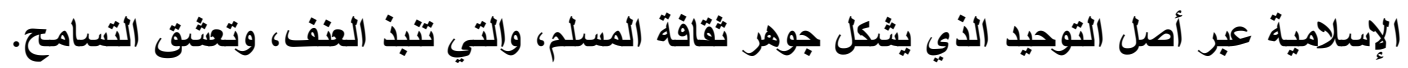

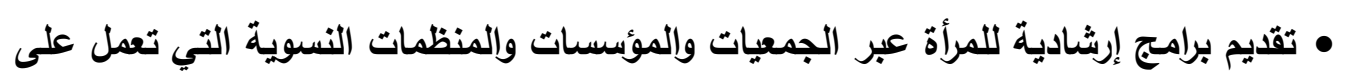

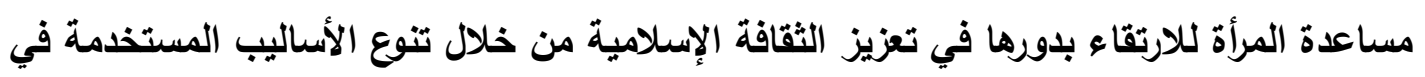
تربية الأبناء التي تتلاءم وروح العصر، مع إكساب مهارة التعامل ومواجهة معترك الحياة.

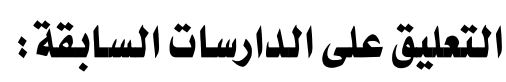

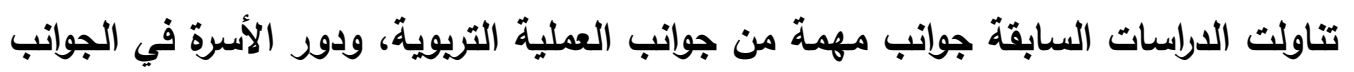

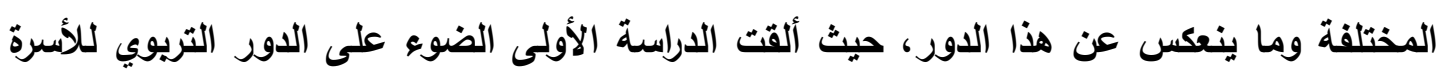

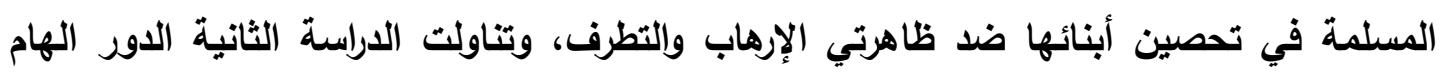

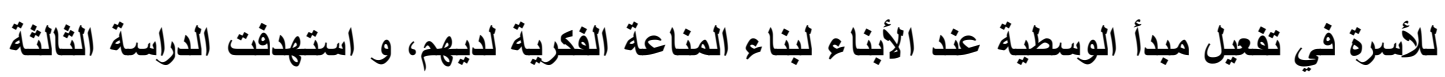

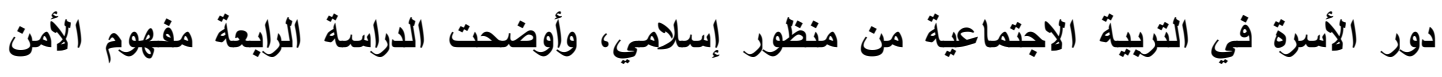

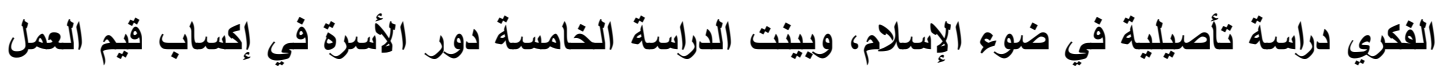

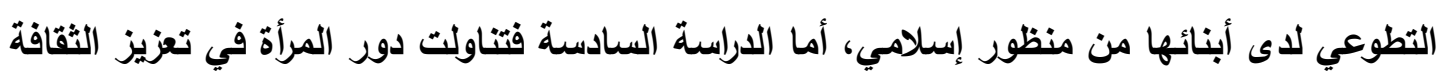

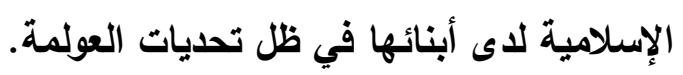

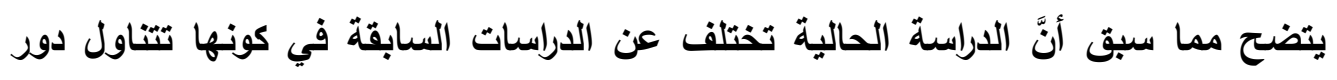

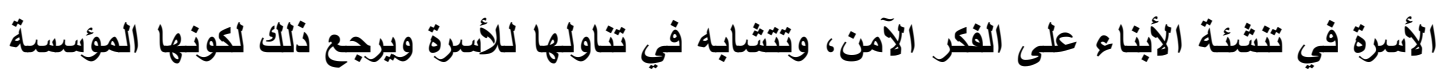

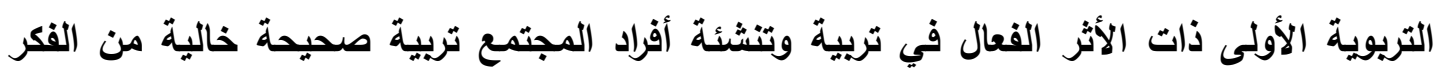

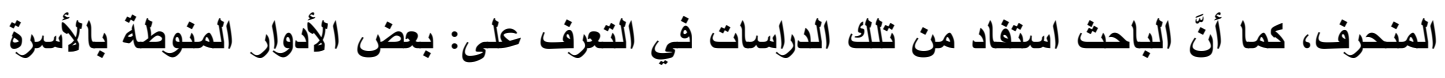
في بناء الفرد ورقي المجتمع، ويعض وظائفها الهامة، كما تعرف منها على أهمية الفكر المعتدل.

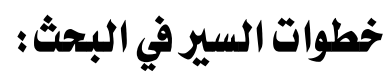

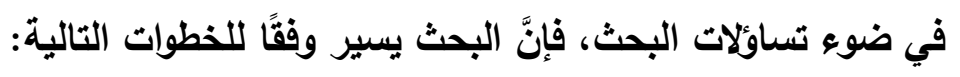

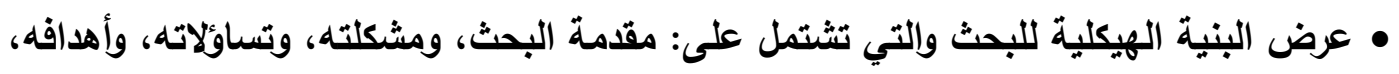
وأهميته، ومنهجه، ومصطلحاته، والداراسات السابقة.

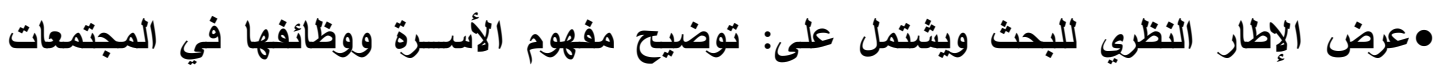

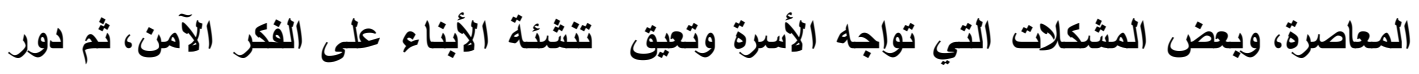

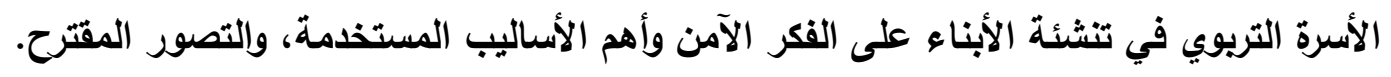




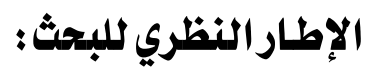

\section{أولًا : الأســــة مفهومها ووظمائفها في المجتمعات المعاصرة:}

(1) مفهوم الأسرة:

الأسرة مؤسسة اجتماعية نجدها في كل المجتمعات البثرية، تتأثر بالتطورات الاقتصادية

والاجتماعية والثثافية التي يعيشها المجتمع، وتعتبر من أهم الجماعات الإنسانية وأعظمها تأثئرًا

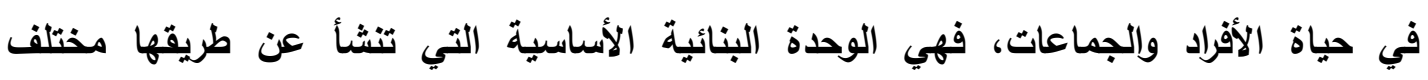

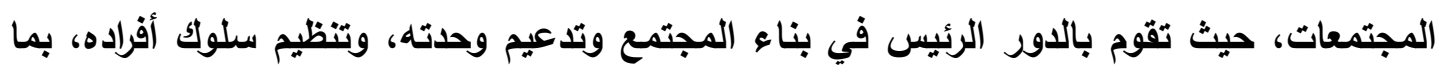

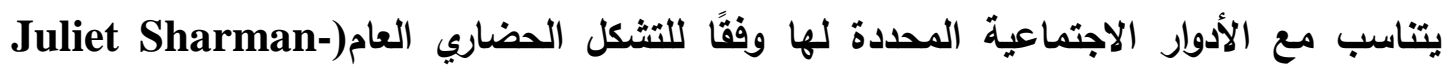

(Burke, 2007

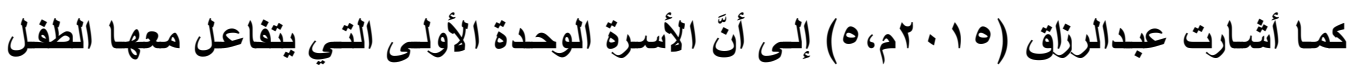

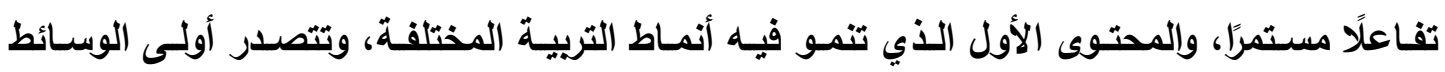

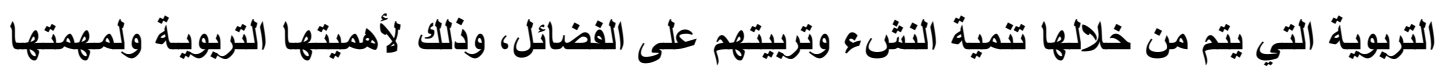

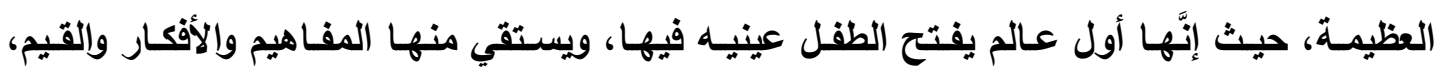
ويجسد الوالدان القدوة الأولية في حياة الطقل.

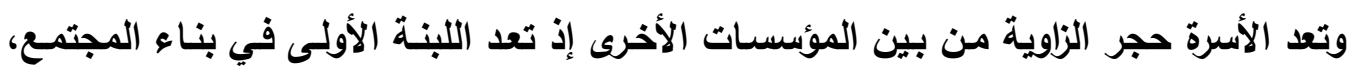

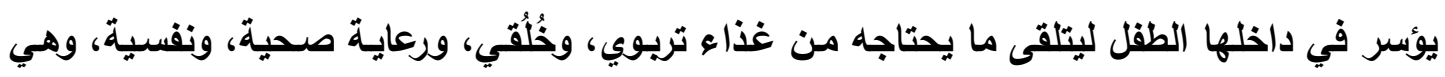

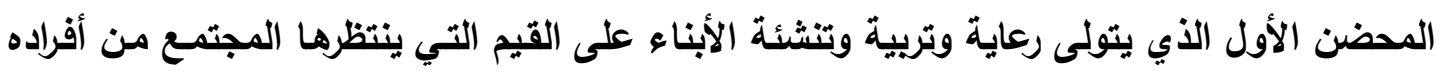

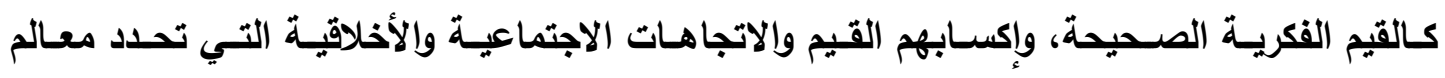

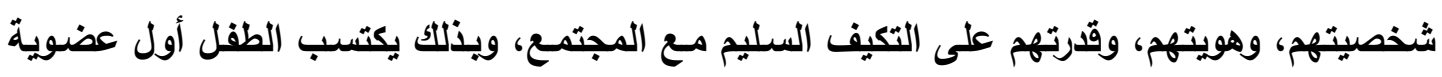

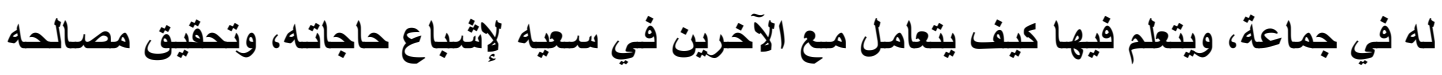

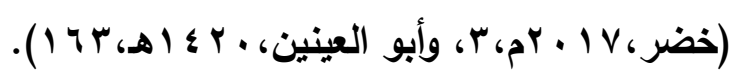

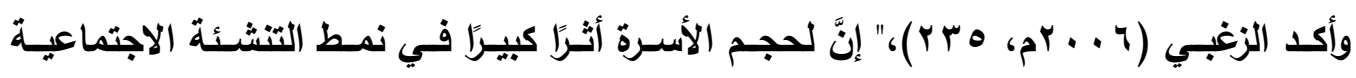

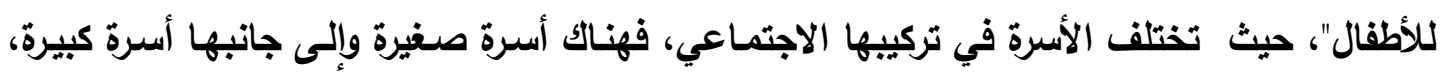

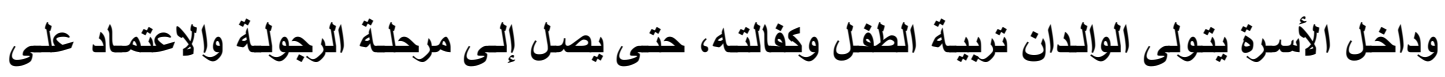

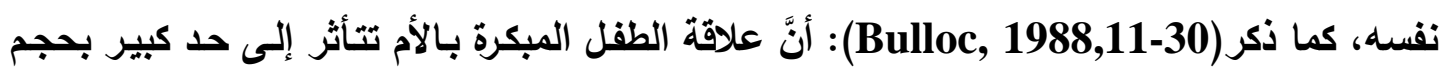

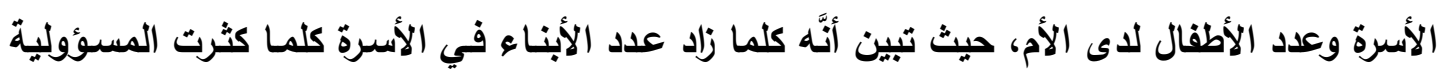
وقلًّ الاهتمام بالأبناء.

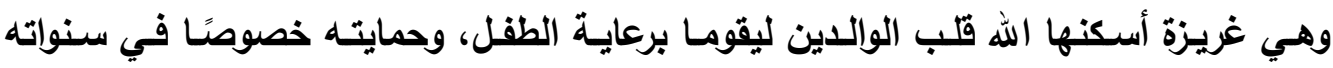
الأولى والتي لها دورها الفعال في تكوينه الوجداني، والأخلاقي، وتكوين السلوكيات الصحيحة، أي أنَّا 
مرحلة الطفولية هي الأسساس الذى يُعْنَّد عليه في تكوين المراحل التي تليها، لأنَّها تعتبر مرحلة

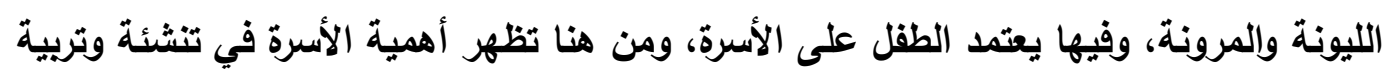
الطقل حتى يُصنِْح فردًا ناجدًا في حياته. ويناءً على ما سبق فالأسرة تمثل أهم المؤسسات الاجتماعية وأخطرها لهاتها لما لها من دور هام في

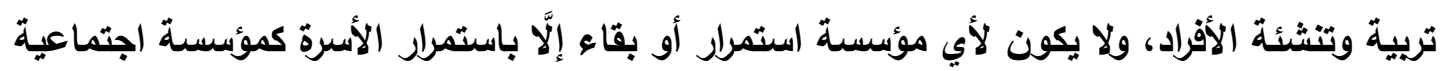

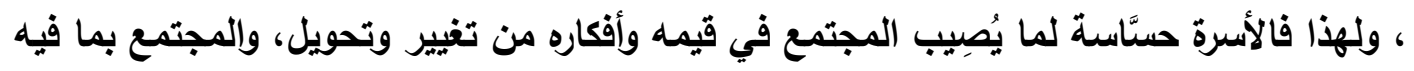

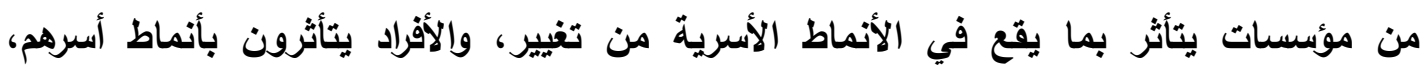

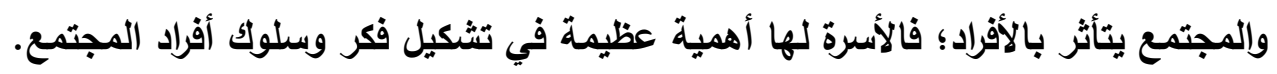

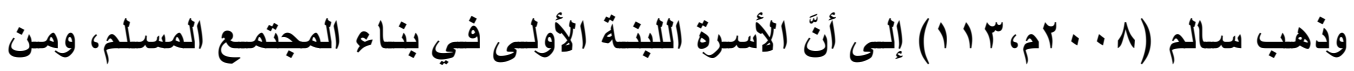

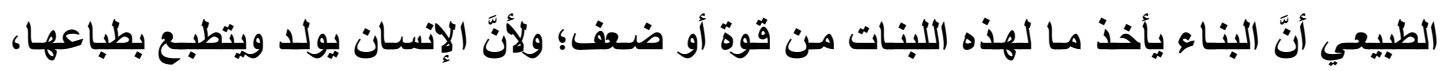

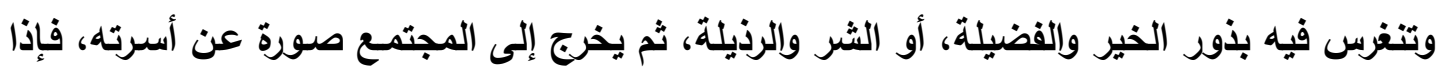

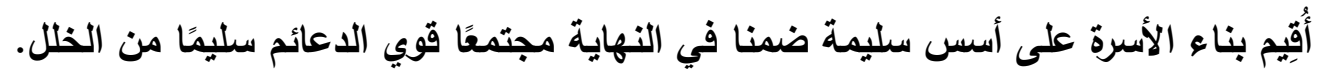

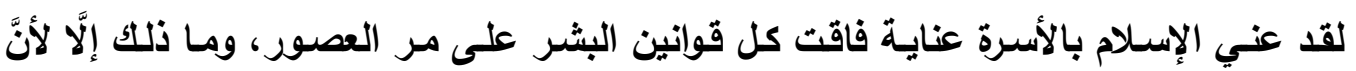

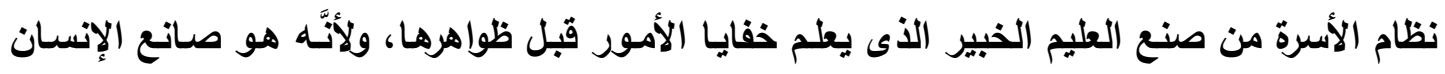

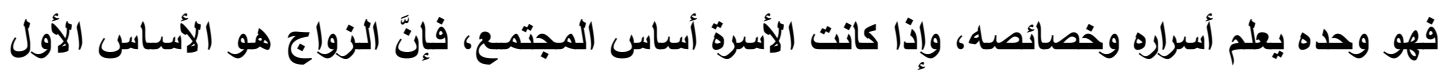

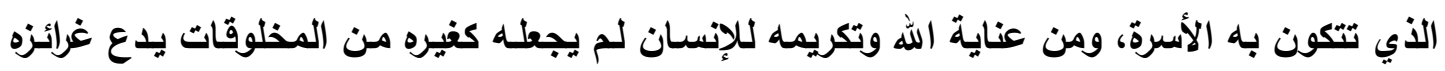

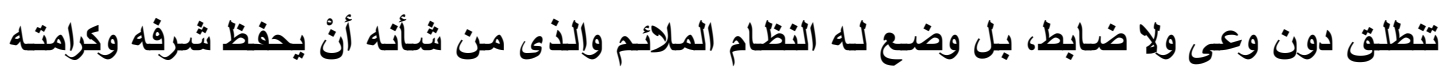

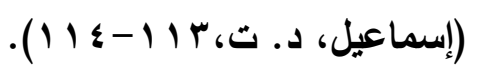

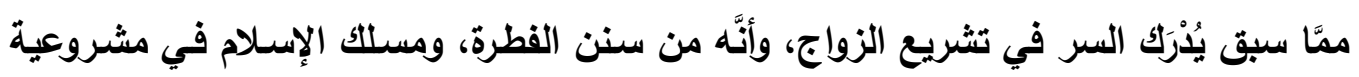

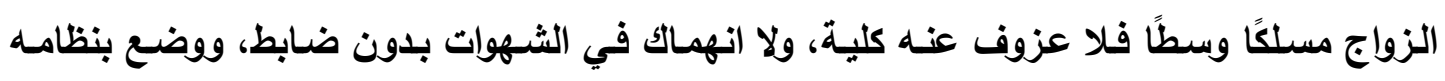

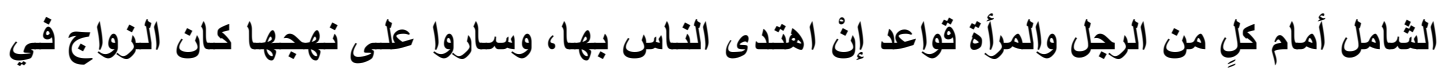
غاية التفاهم، وكانت الأسرة في غاية السعادة.

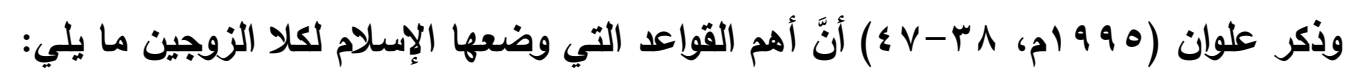

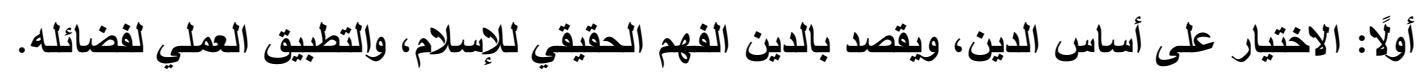

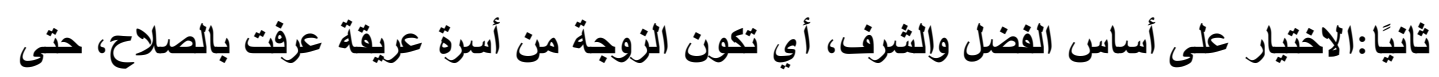

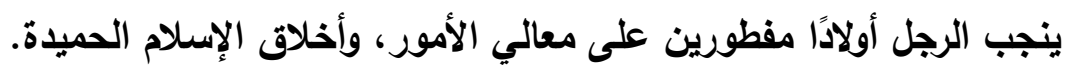

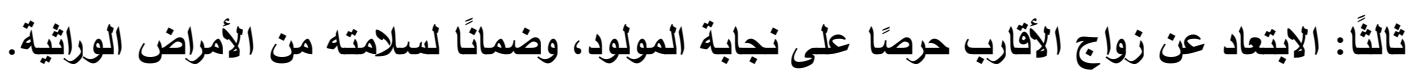

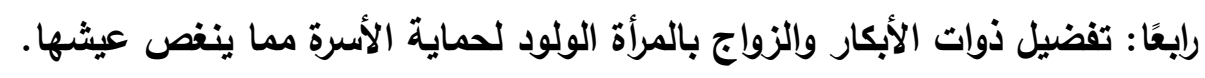


إنَّ حسن اختيار الزوجين يحرر المجتمـع من الأمراض، والاتحـلال الخُلْقِي، ويحقق التعاون

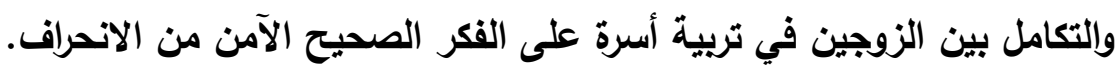
(r) و وظائف الأسرة في المجتمعات المعاصرة:

تتلقى الأسرة الطفل وهو صغير أثبه ما يكون بالعجينة القابلة للتشكيل، وتتولى تثكيلها حسب ثقافتها، ويجانب ذلك تمثل الأسرة الجماعة المستقرة التي يتربى الطقل في رحابها، والتي

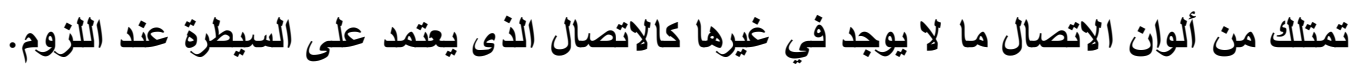

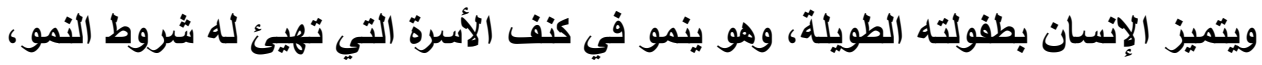

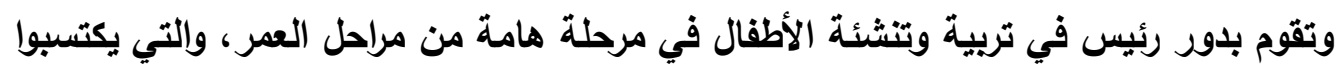
فيها السلوك، والأخلاق، والمعتقات، والقيم، والفكر السليم وتتكون لديهم شخصية متميزة من خلال التفاعل مع أفراد الأسرة.

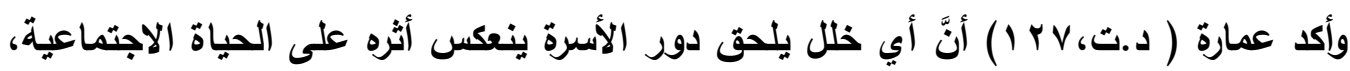

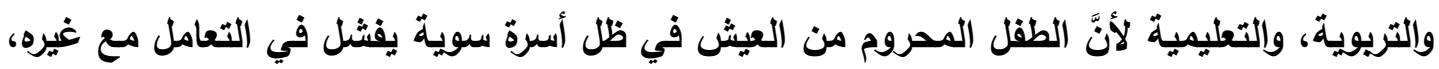

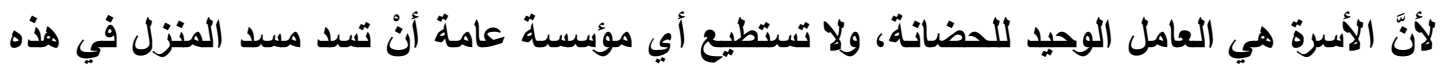

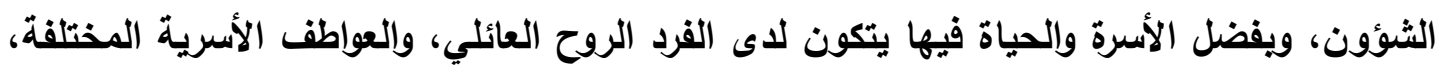

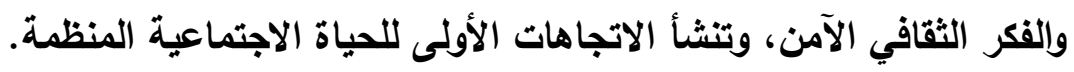

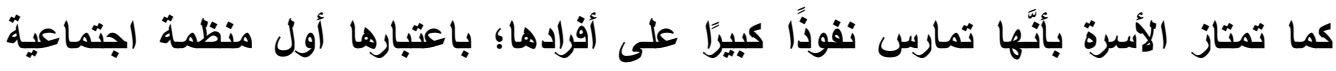

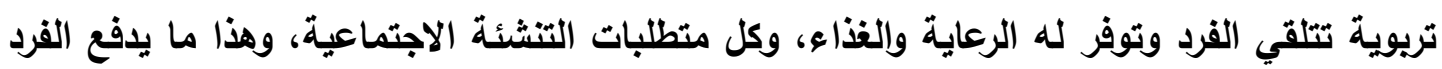

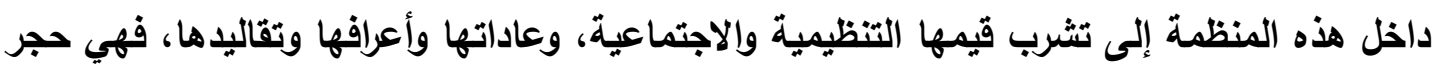
الزاوية في البناء الاجتماعي والفكري للفرد في المجتمعات المعاصرة.

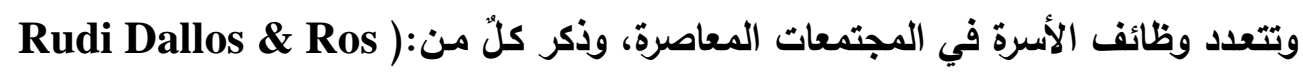
2015, Draper

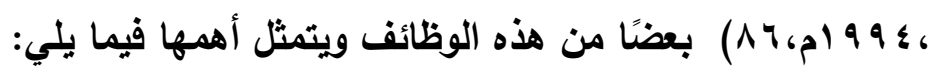

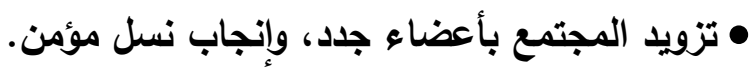

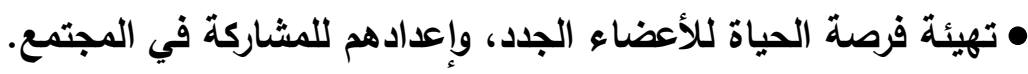
• • حماية ورعاية الأبناء، والتثكيل الاجتماعي لسلوكهر.

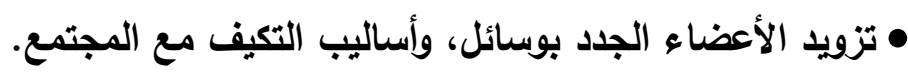
• تنمية شخصية الأبناء في جوانبها المختلفة: ( العقلية والفكرية والجسمية الجئية ل....).

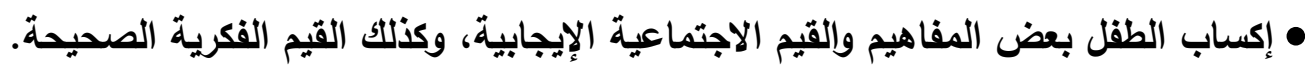
• زيادة كفاعة الطقل العملية والعقلية وتنمية روح الإبداع. 
• تحقيق الأمن النفسي والفكري للطفل بنقل الثقافة بعد تفسيرها، وتقويمها، وإختيار الهام منها. • الترفيه، والتفاعل العاطفي، وتوفير الحاجات الأساسية للأبناء.

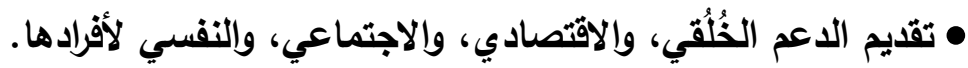
• صبغ سلوك الطفل بلون اجتماعي من خلال أسلوب التفاعل العائلي داخلها. • • تعليم الطفل اللغة، واكسابه الخبرات في المجالات المختلفة.

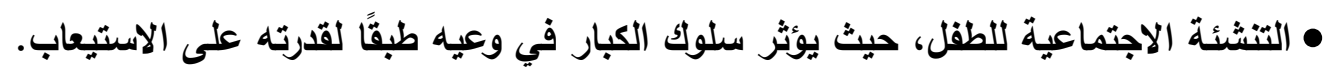

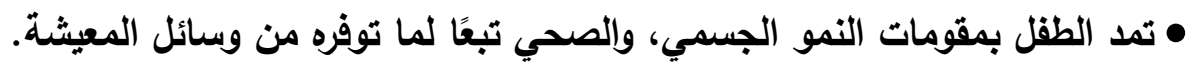
• تعليم الطقل شعائر الدين، وطريقة التعبير، وأصول التعامل مع الآخرين.

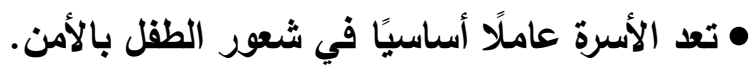

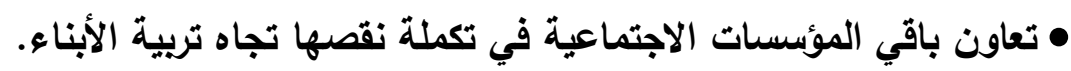
• تقوم بتنشئة وتعليم الطفل الفكر الصحيح الآمن البعيد عن الانحراف.

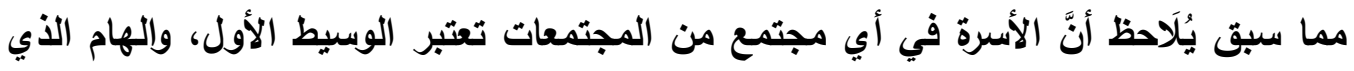

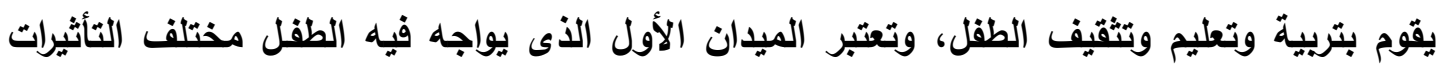

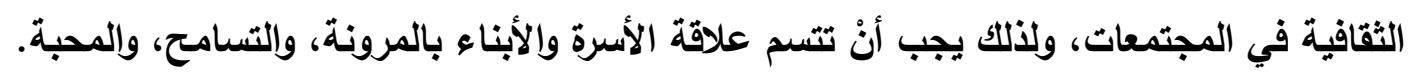
ثانيًا : بعض المكلات التي تواجه الأسرة وتعيق تنشئة الأبناء على الفكر الآمن:

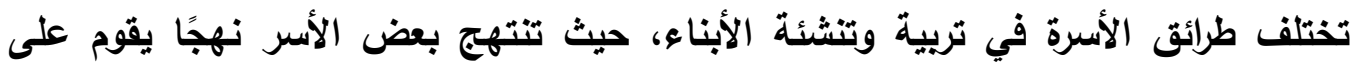

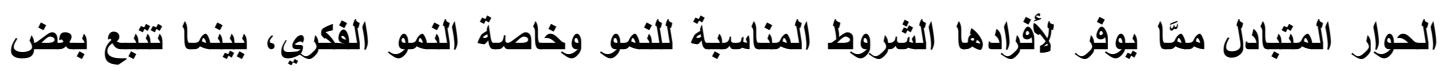

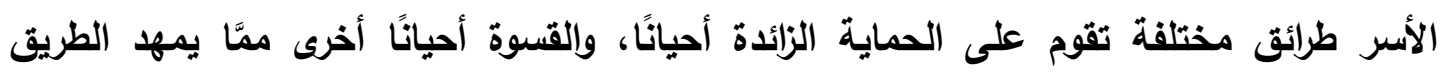

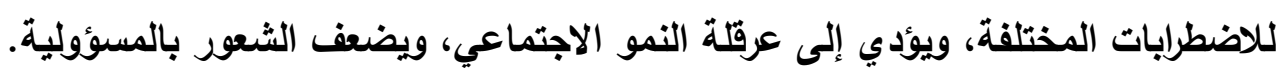

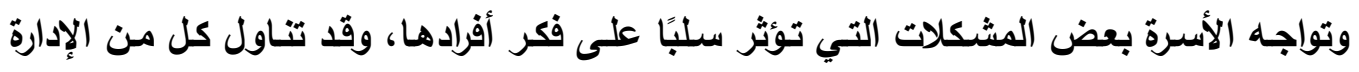

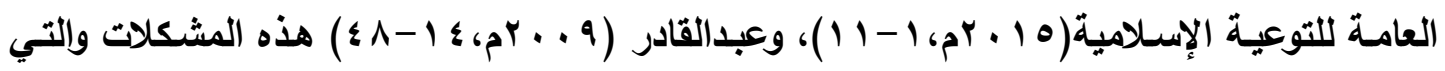

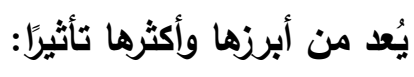
• ضعف الهوار الأسري:

تواجه الأسرة الكثير من التحديات والمستجدات والتغيرات السريعة والثشاملة لكل مناشط الحياة

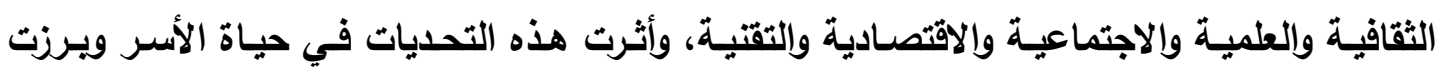

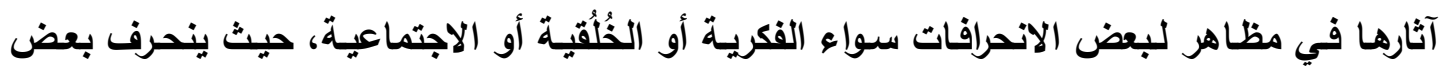

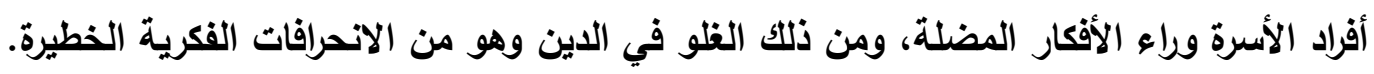

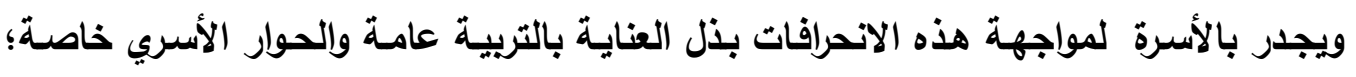

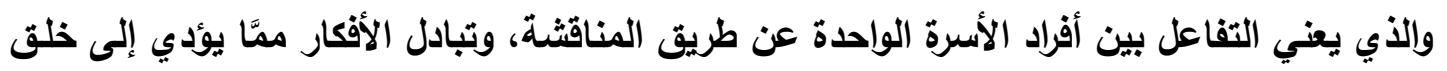


الألفة والتواصل، ويساعد على البعد عن الانحراف الفكري، كما يُعَّلّم أفراد الأسرة احترام الرأي الآخر ،

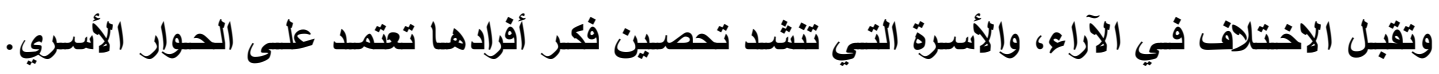

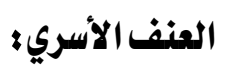

يؤثر العنف الأسري في تتشئة الأبناء على الفكر الآمن من الانحراف، ويتم داخل الأسرة من

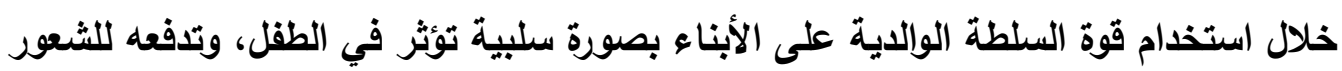

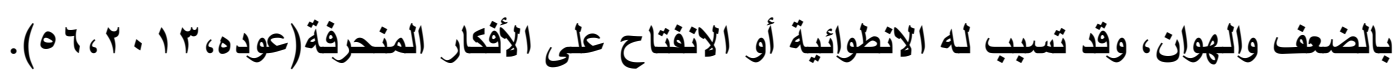

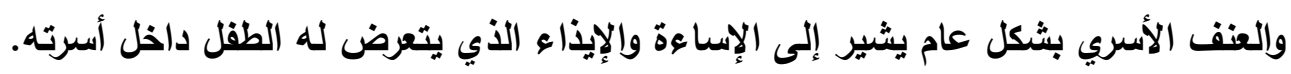

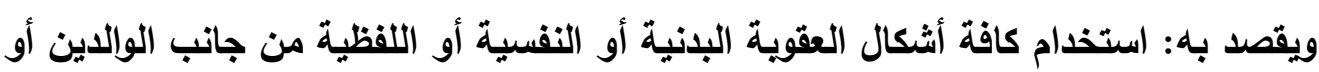

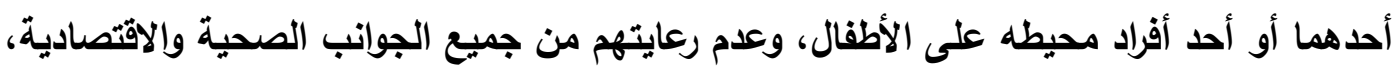

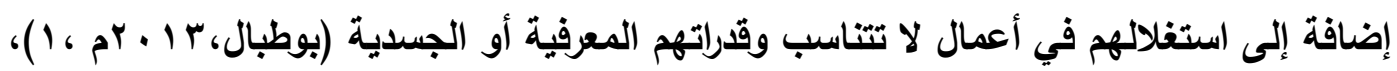

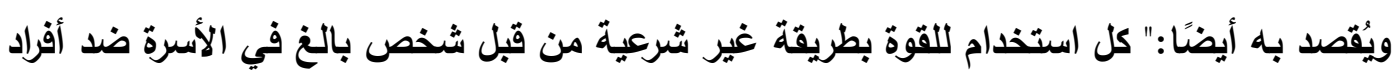

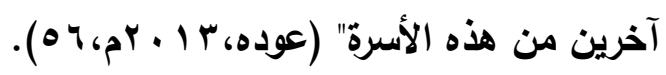

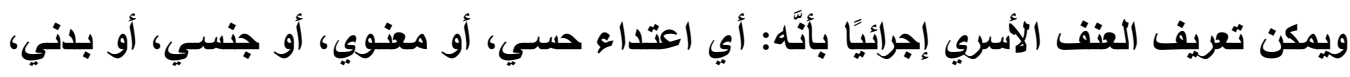

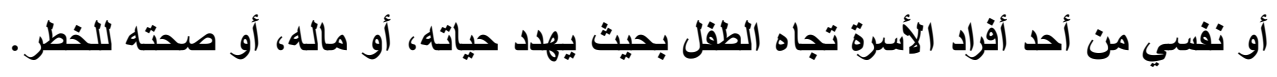

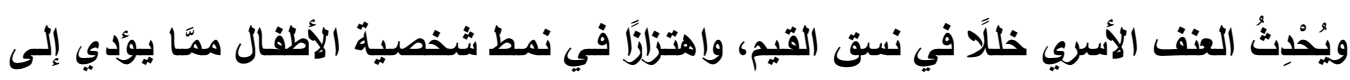

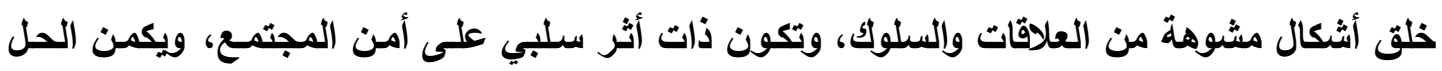

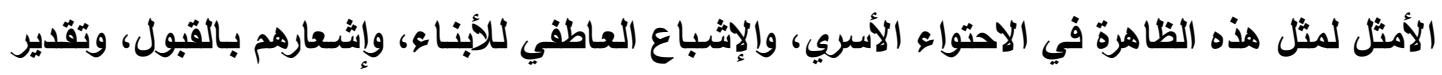

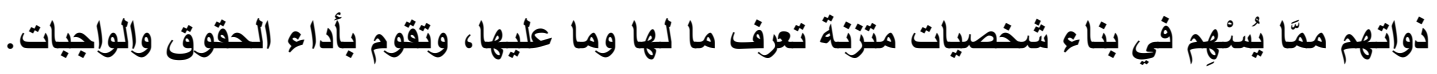

\section{•ضعف تربية الابناء على تصمل المسؤولية؛}

من مسؤولية الوالدين تربية الأبناء على تحمل المسؤولية، وأداء الماء الأمانة، والقيام بأداء

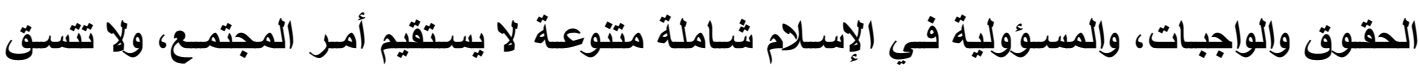

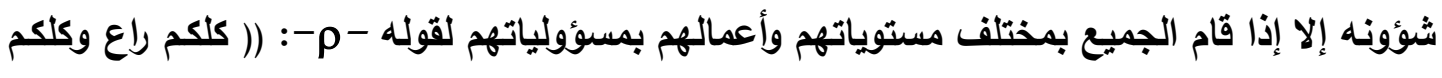

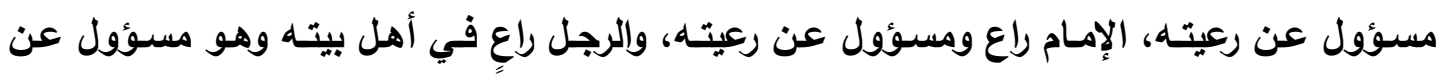

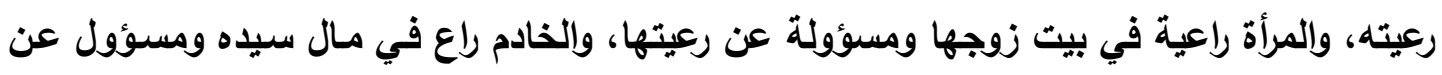

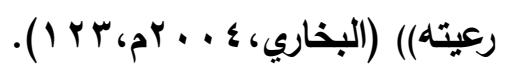

ولعلاج هذه المظاهر لابد من التربية على تحمل المسؤولية من قبل المبل الوالدين حيث يتم تحميل

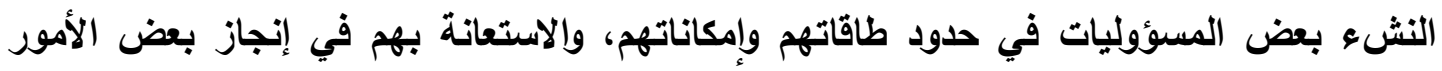

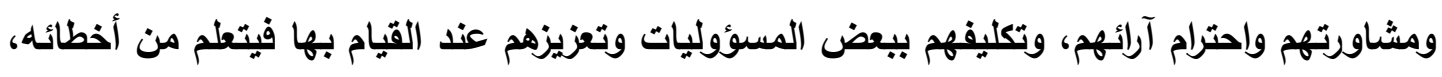

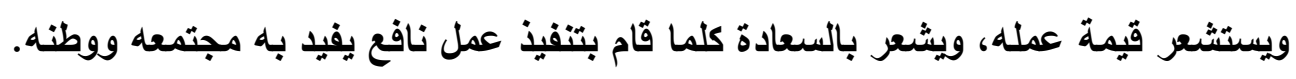


•الفراغ:؛

الفراغ داء قاتل للفكر والعقل والطاقات الجسمية، إذ النفس لابد لها من حركة وفكر وعمل فإذا

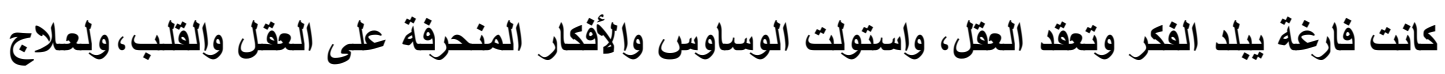

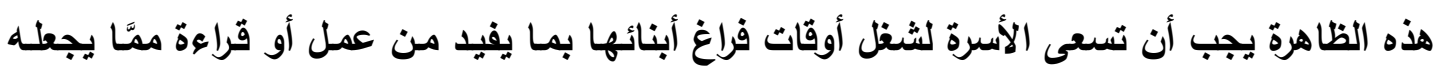
عضوا سليمًا قد حصل على الأمن الفكري وابتعد عن الانحرافات الفكرية والذهنية.

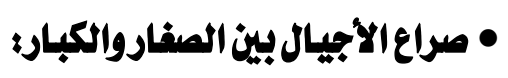

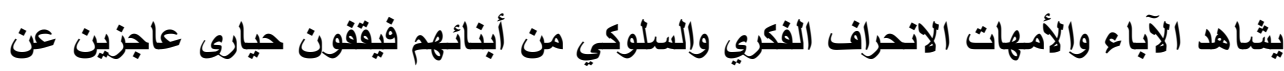

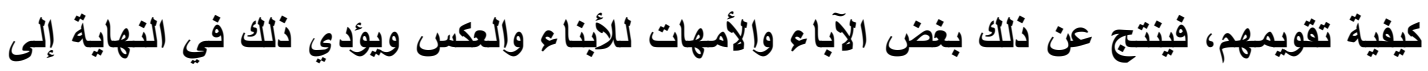

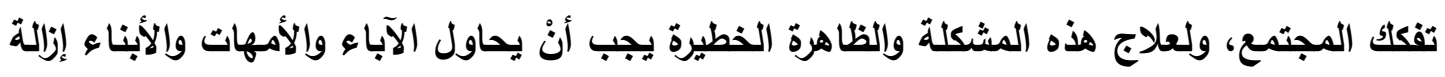
الصراع والجفوة بينهم حتى لا يصل الأمر للانحراف الفكري والسلوكي.

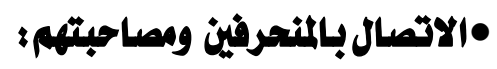

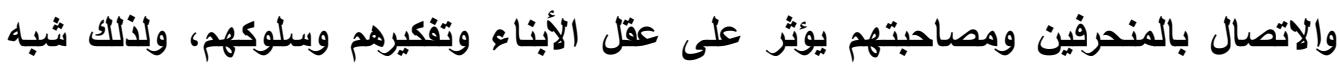

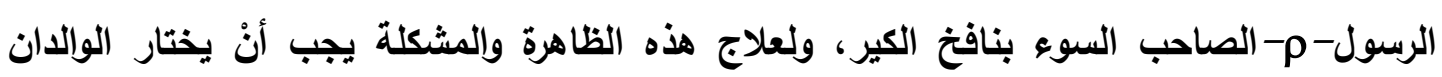
لصحبة أبنائهم الأخيار من الأقثران حتى يكتسب الابن منهم الصفات الحسنة والتفكير الصحيح.

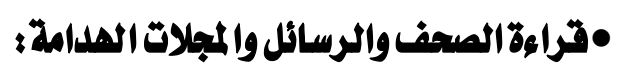

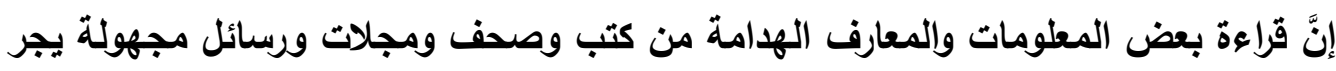

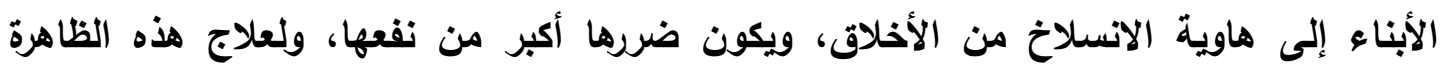

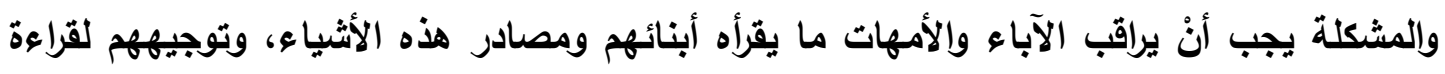
الكتب الثقافية المفيدة الخالية من الأفكار الهـامة.

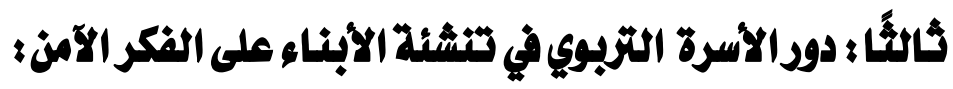

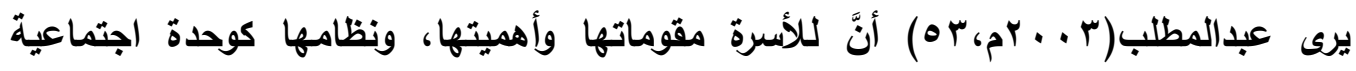

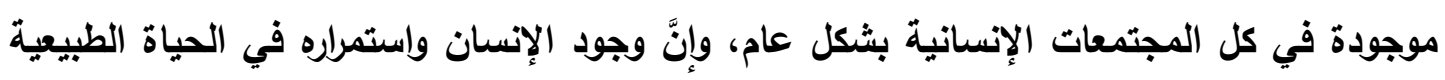

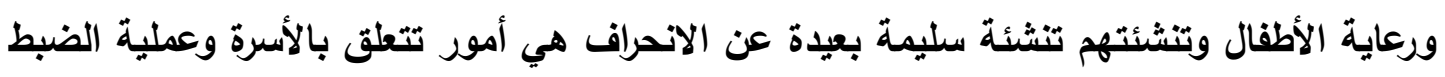
والتنشئة الاجتماعية. ويولد الطقل خاليًا من أي شيء يحدد شكل تعامله مع المواقف، والأهداف التي تنتظم عليها

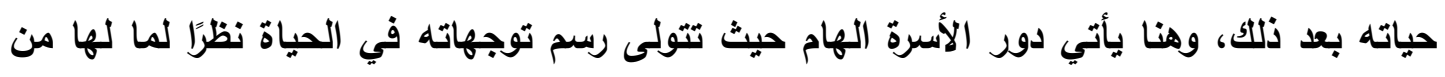

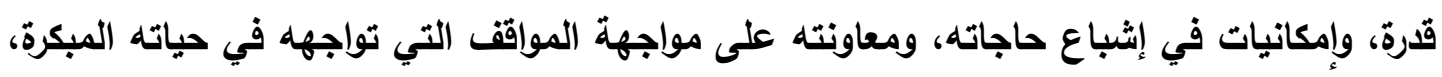

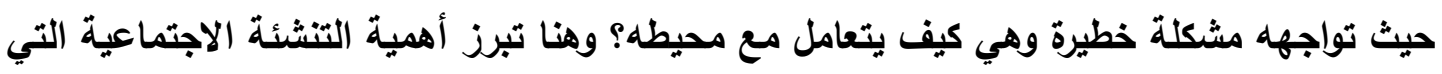


تتم عن طريق الأسرة والتي تكتسب الطفل كيفية الحكم على الأثشياء، وتتأثر تلك العملية بالجو

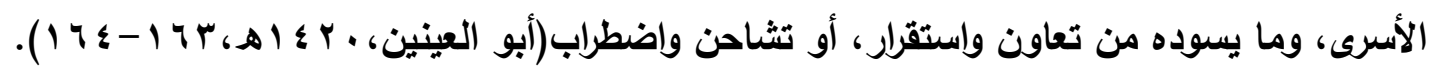

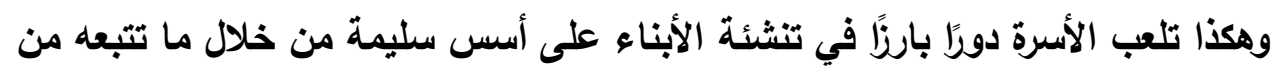

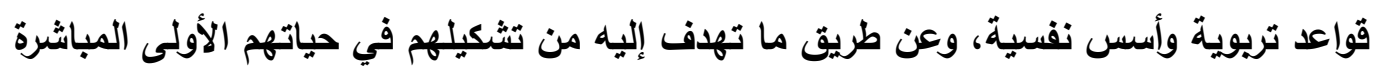

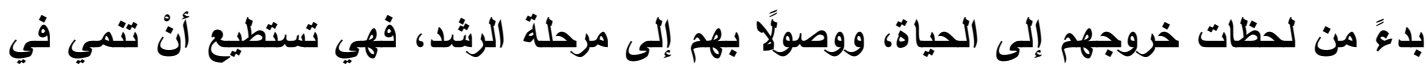

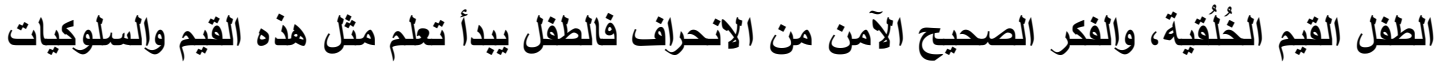

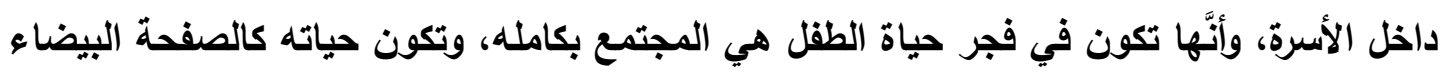

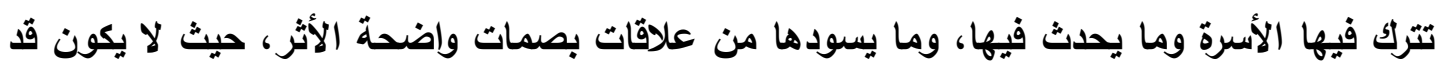

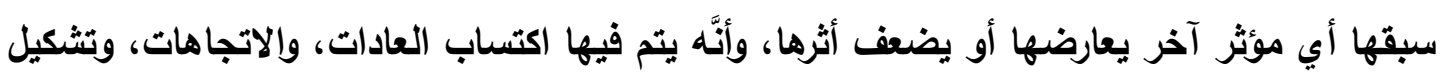

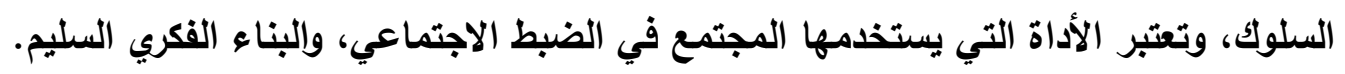

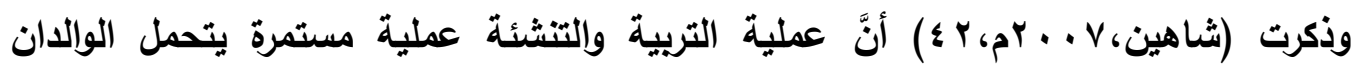

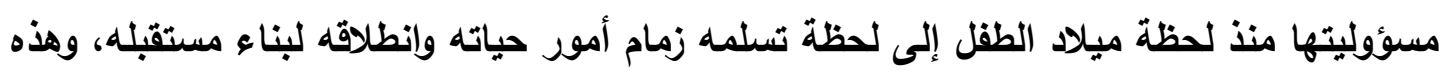

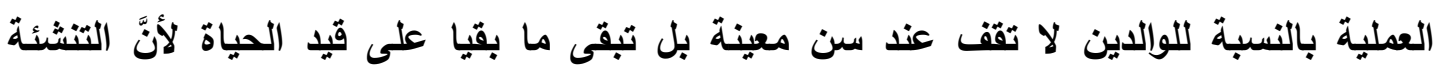

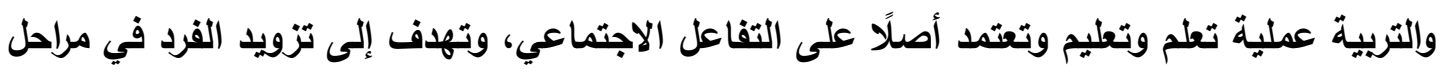

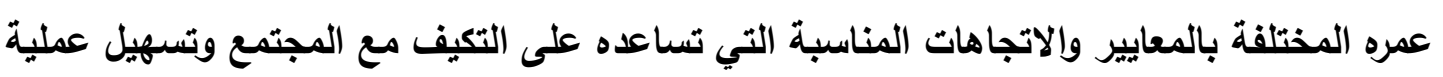
الاندماج في الحياة.

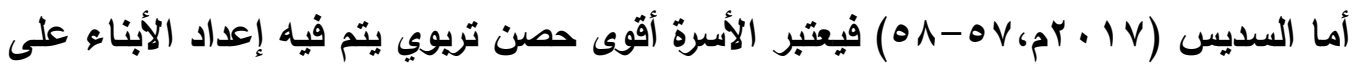

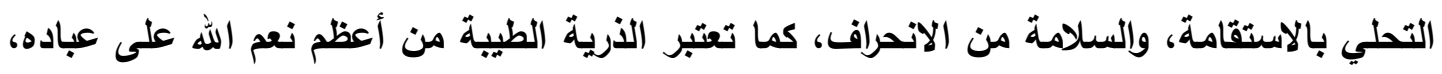

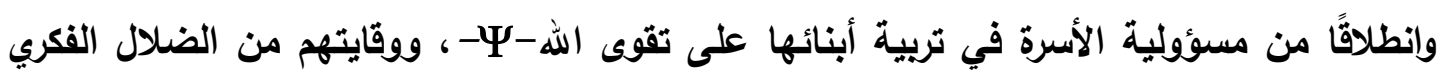

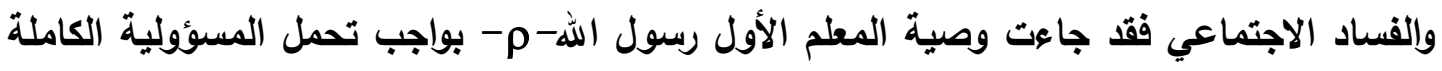

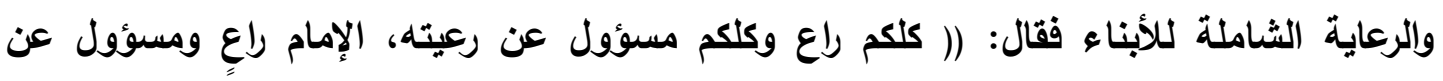

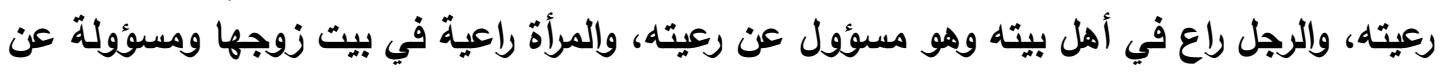

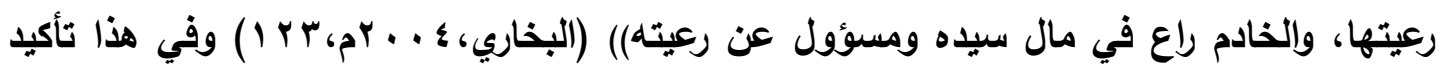

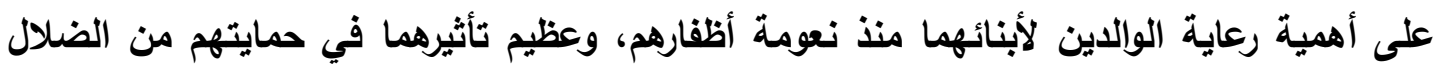
والانحراف الفكري والثقافي.

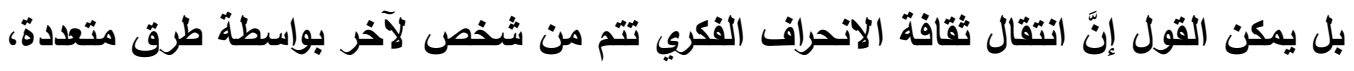
ولذلك من أهم أساليب الوقاية من الانحراف الفكري داخل الأسرة هو: إعداد الآدآياء للأبوة والأمهات

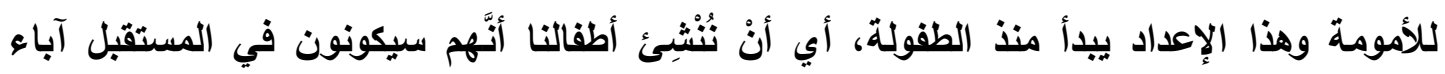
وأمهات يتصفون بالاتزان والاعتدال والثعور بالمسؤولية تجاه أبنائهر. 


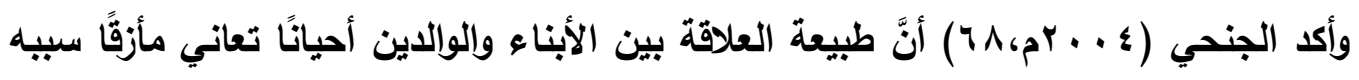

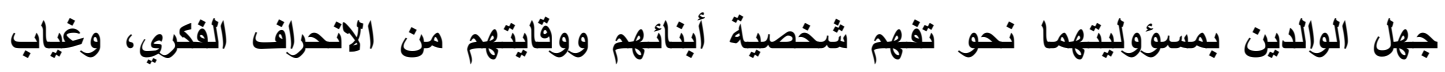

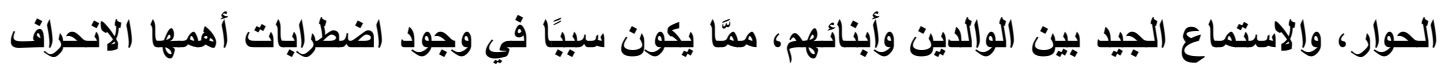

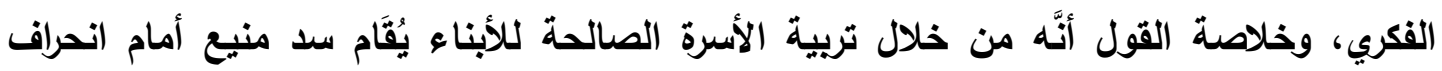
الأبناء الفكري، وتنتشر القيم السمحة. يتضح من خلال دور الأسرة في التربية، وفي إطار رعايتها للنمو المتكامل لثخصية الأبناء،

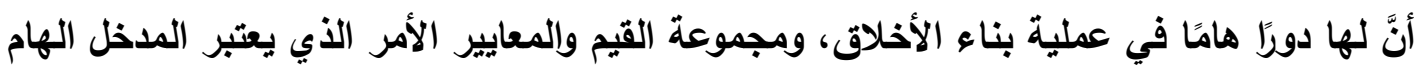

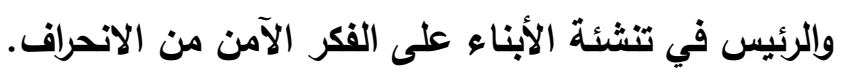

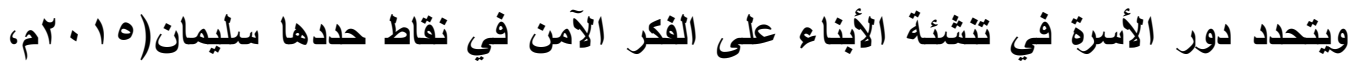

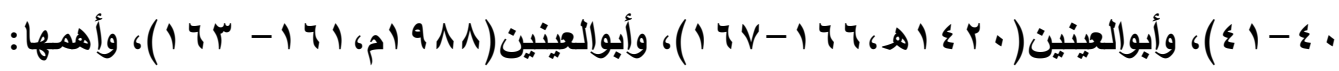
1. مساعدة الأبناء على تأكيد الإيمان بالله بكافة الطرق المناسبة سواء الهاء بالكلمة أو السلوك.

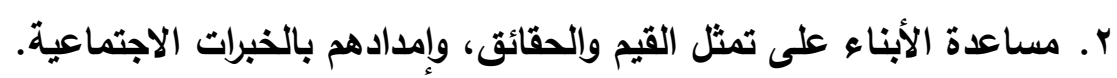

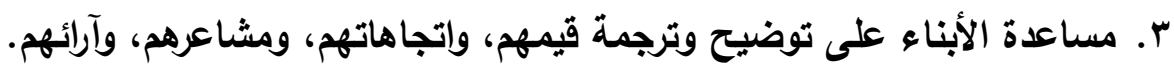
؛. توجيه الطفل إلى ما يجب أن يفطله في المواقف المختلفة. ه. تهيئة المناخ المناسب المساعد على اكتساب القيم والأخلاقيات الفاضلة.

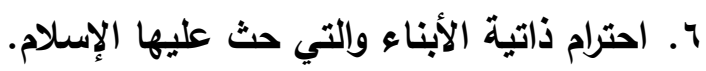

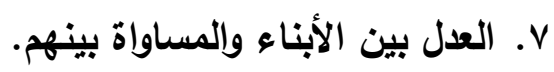

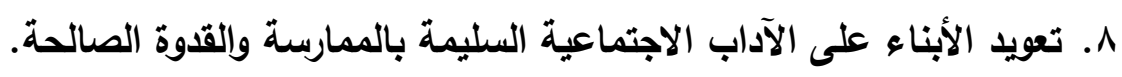

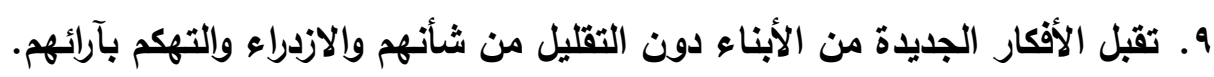

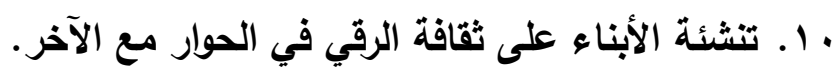

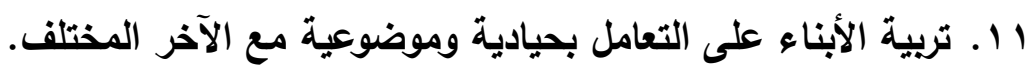
r r ا ـ تثقيف الأبناء وتهذيب سلوكهم بالفكر الصحيح البعيد عن الانحراف.

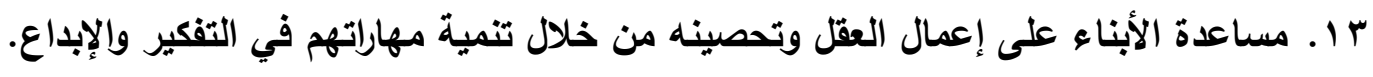
؛ ا. استقبال المعلومات وتنقيتها وفلترتها حتى تضمن عدم وصول الفيناء الفكر المنحرف.

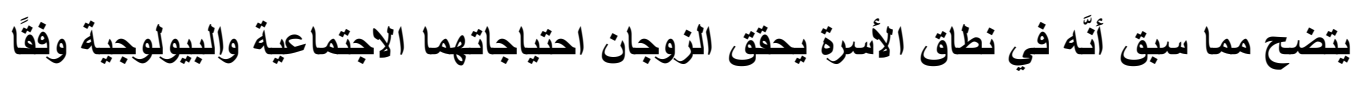

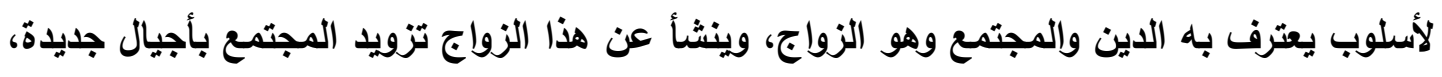

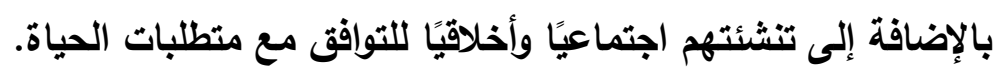

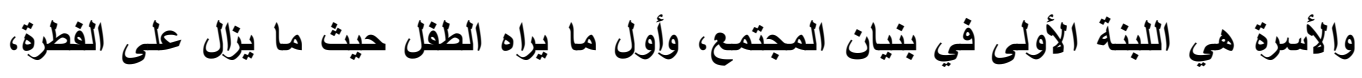

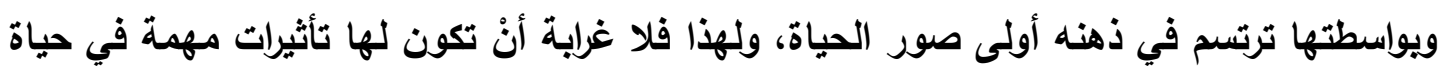


الفرد، فهي تشكل فكر الطفل في فترة يكون فيها سهل الانقياد؛ وفي هذا يقول الرسول الكريم-م- :

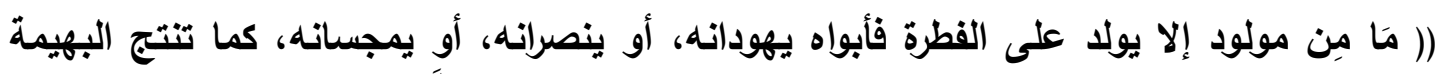

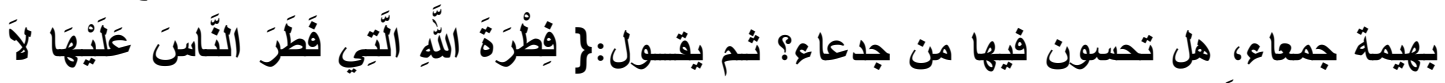

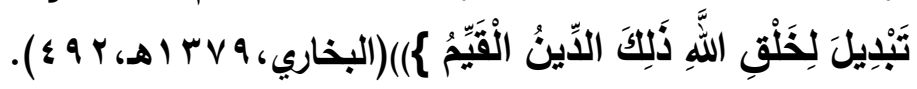

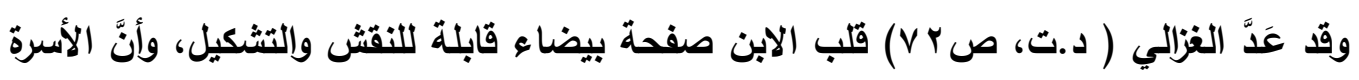

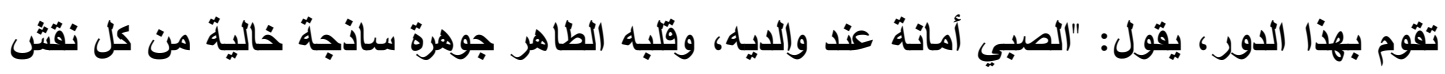

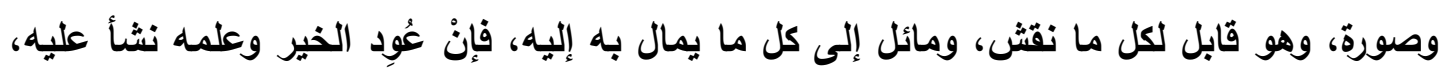

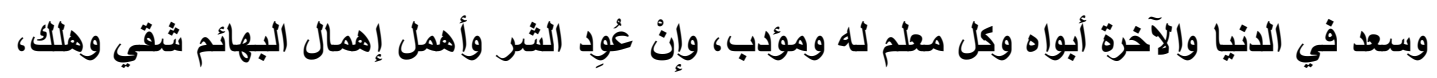

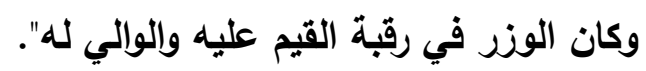
ويتمثل الدور الذي تقوم بـه الأسـرة تجـاه أبنائها في وقايـة فكرهم مـن الانحراف مـن خـلال

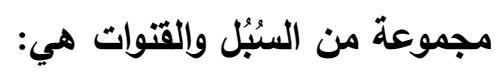
أ - توفير المناخ الأسري المناسب؛

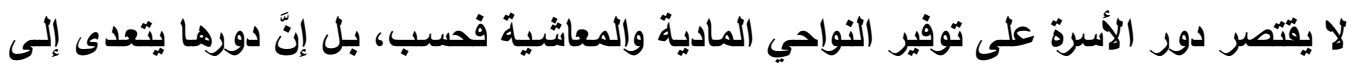

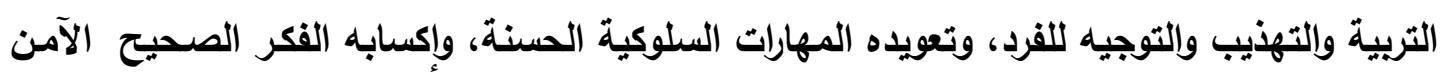

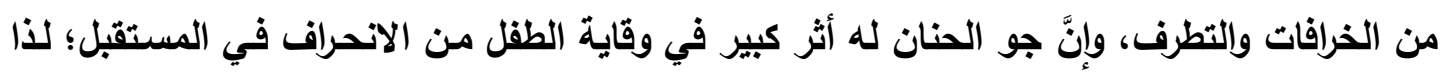

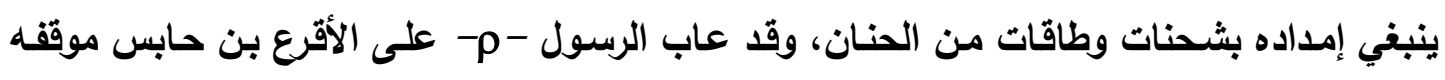

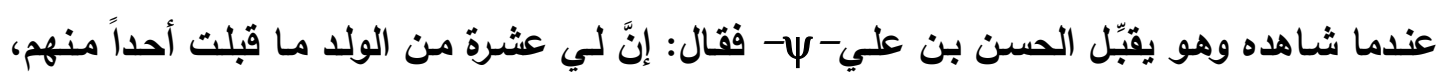

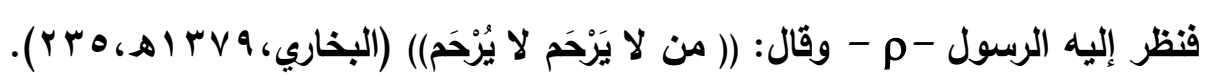

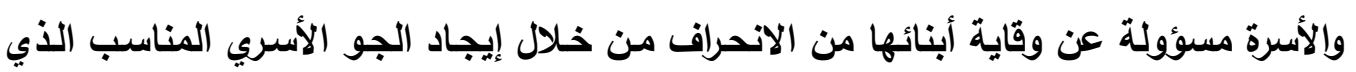

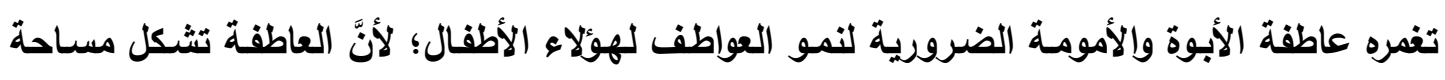

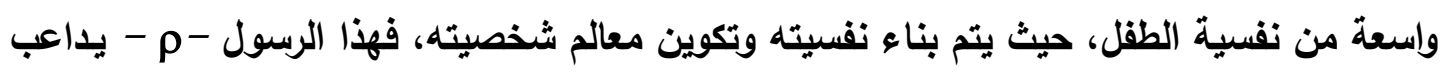

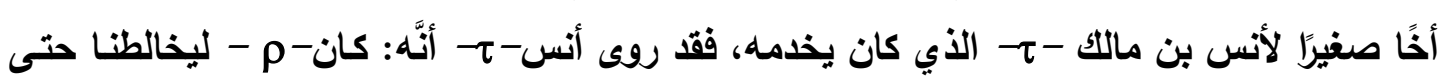

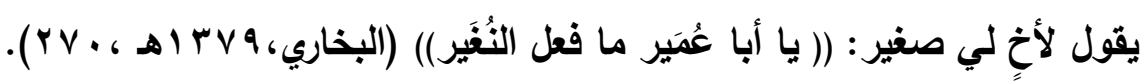

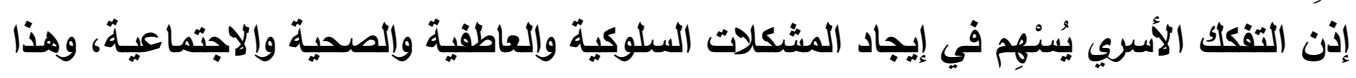
يدل على أهمية العطف والحنان في هذه الفترة من حياة الطفل من حيث نموه بثكل متزن وسليم.

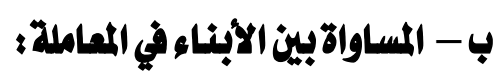

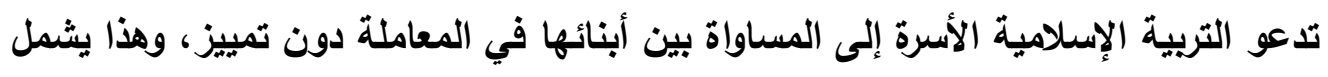

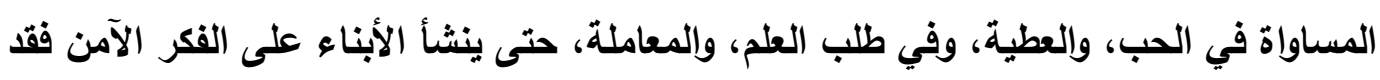




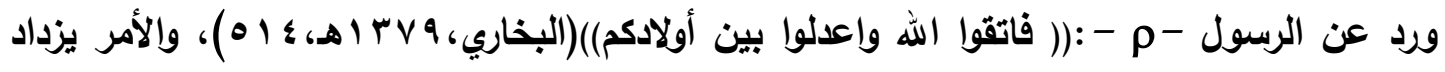

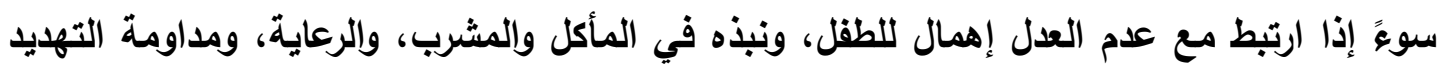

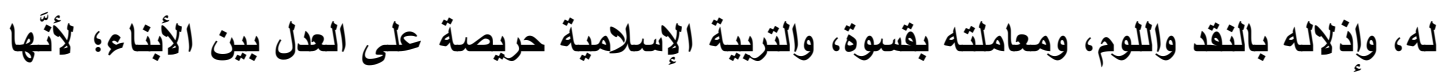

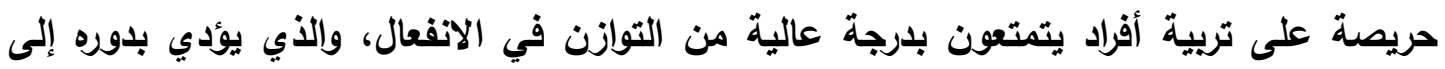
تكوين شخصية سوية، وتُصنبح تلك الثخصية صاحبة فكر مستقيم بعيدًا عن أي تثشويه أو انحراف.

\section{ع - مسن اختيارالاصحاب:}

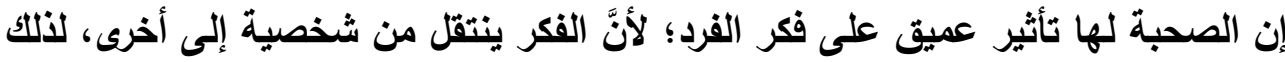

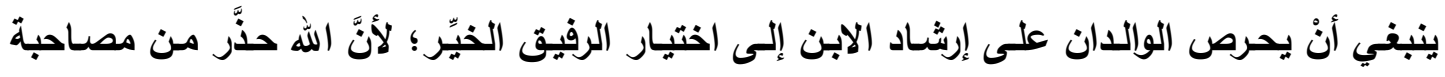

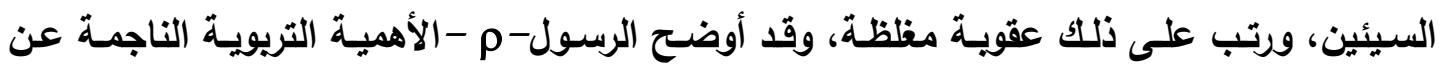

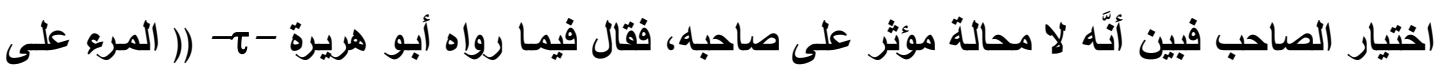

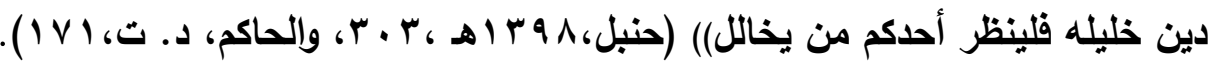

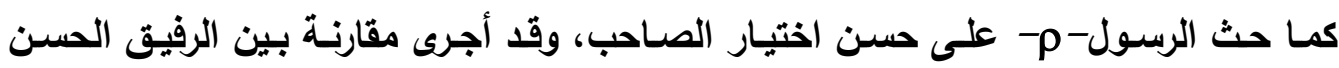

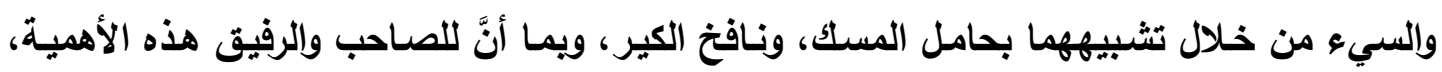

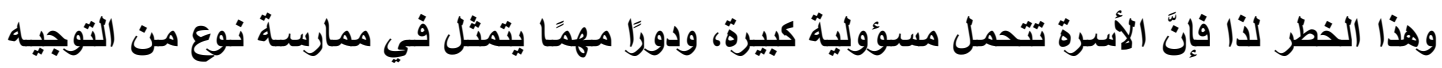

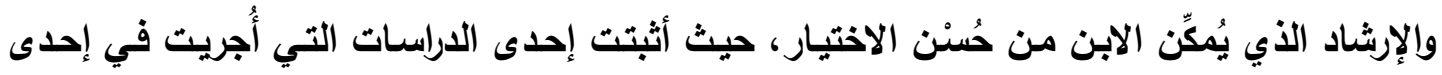

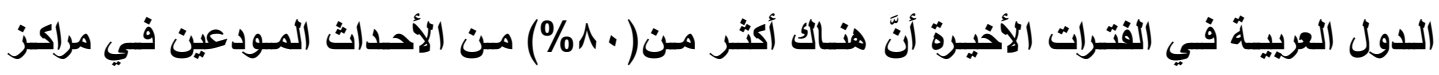

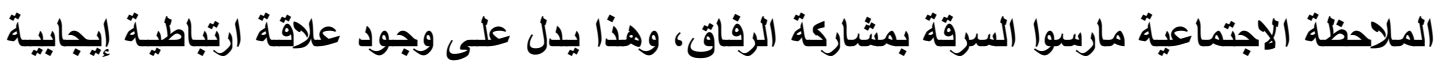

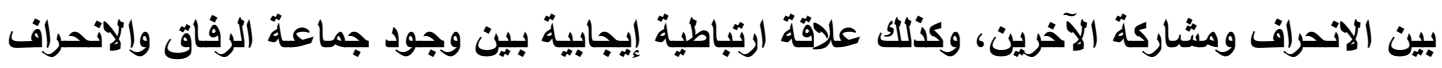

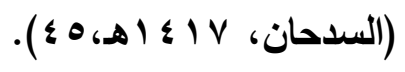
إذن ينبغي على الأسرة مراقبة الأبناء في صحبتهم بحيث تكون صحبة خيّرة، ومراقبة أفكارهم ومعتقاتهم بحيث تكون سليمة وآمنة من الانحراف، ومراقبة توجهاتهم بحيث تكون صحيحة.

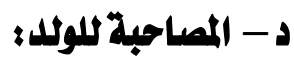

ينبغي أنْ يعامل الولـا معاملة تتناسب والمرحلة التي يمر بها، ابتداءً من المراحل الحياتيـة

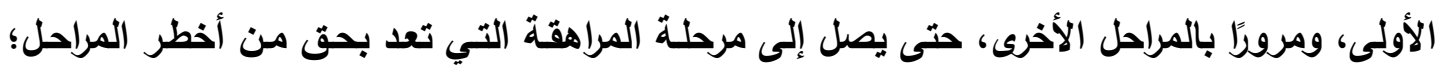

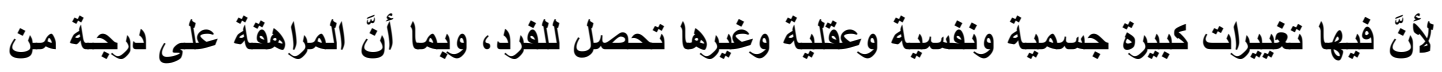

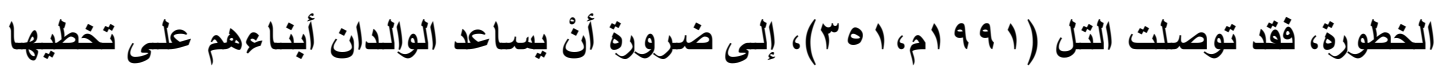

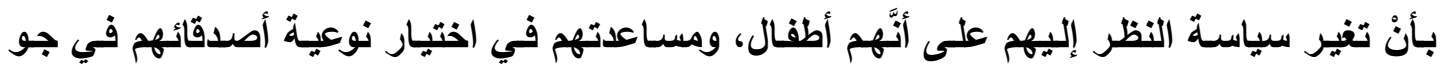

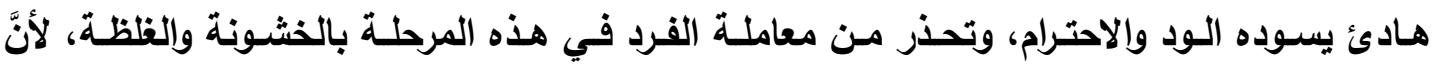

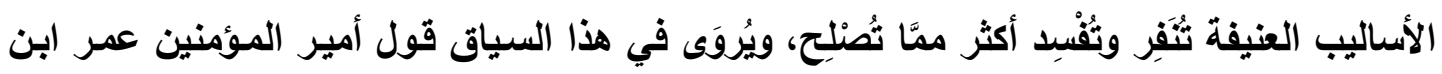


الخطاب- - : (يُرخى الصبي سبعًا، ويُستخام سبعًا، وينتهي طوليه في ثلاث وعثرين، وعقلّه في

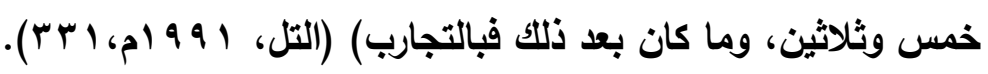

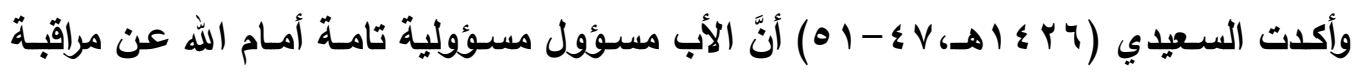

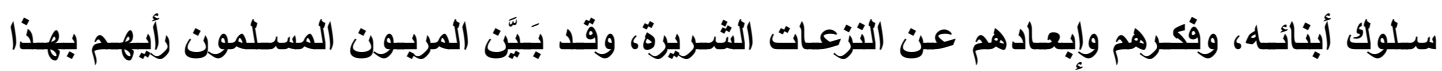

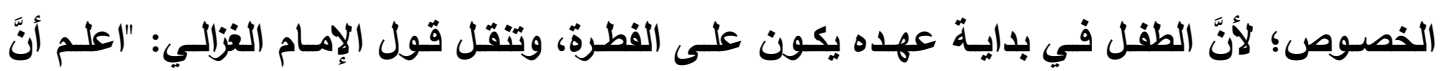

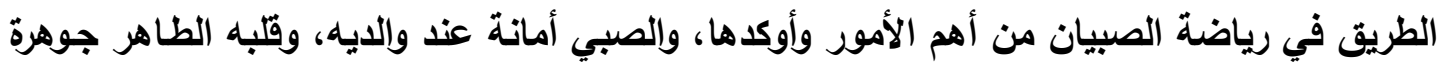

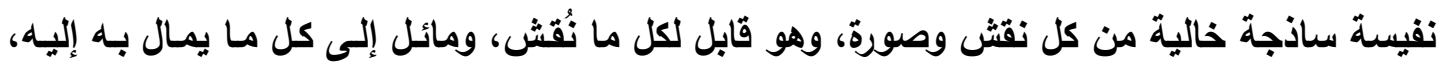

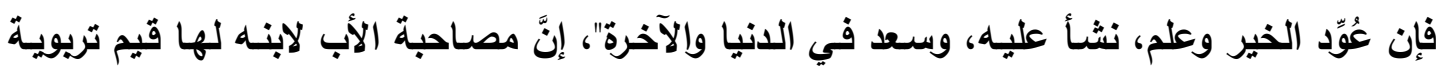

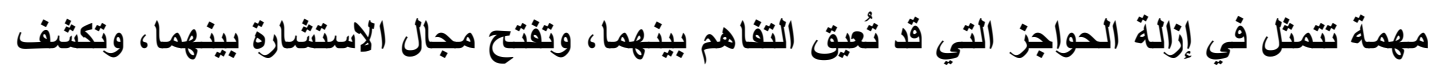
عن القدرات الفعلية التي يمتلكها الولد.

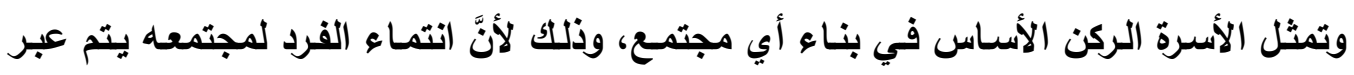

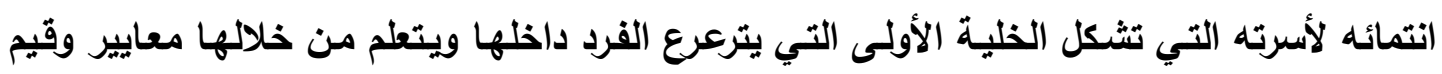

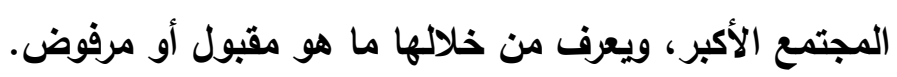

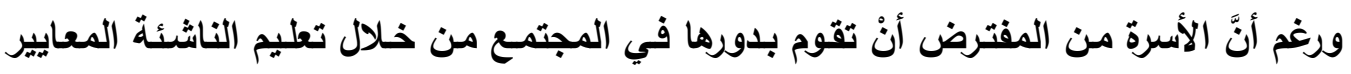

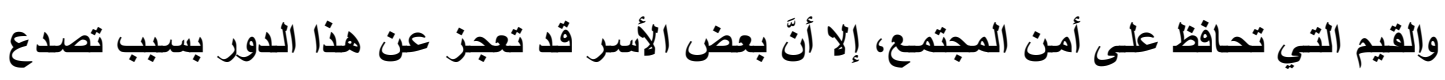

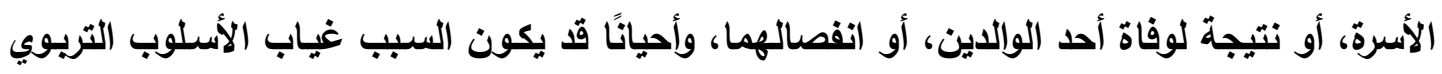

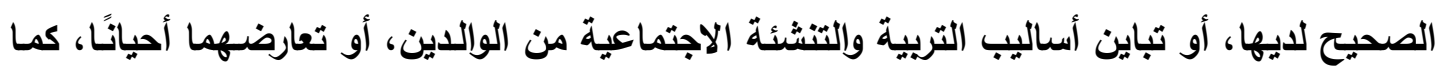
أنَّ التحولات والتغيرات الاجتماعية التي يمر بها المجتمع قد تنعكس بدورها علئ التهى البناء الأسري.

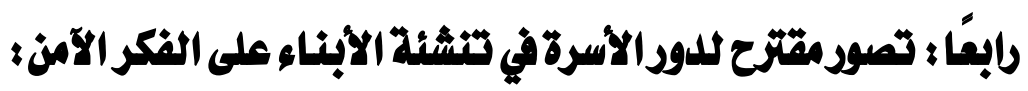

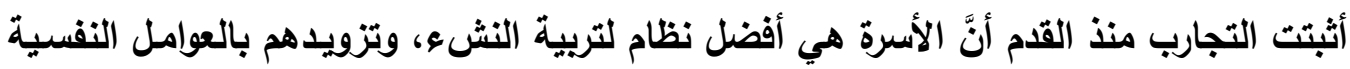

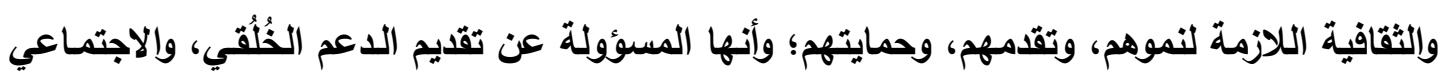

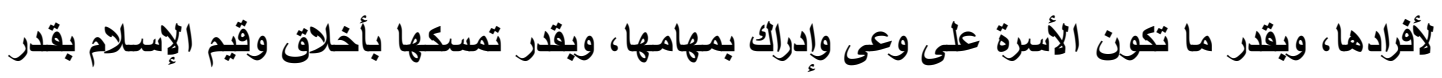
ما تتنج أفرادًا صالحين يصلح بصلاحهم المجتمع.

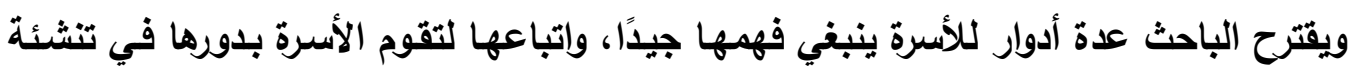

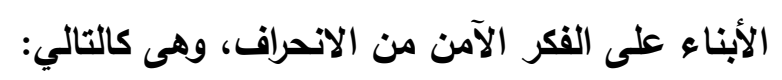

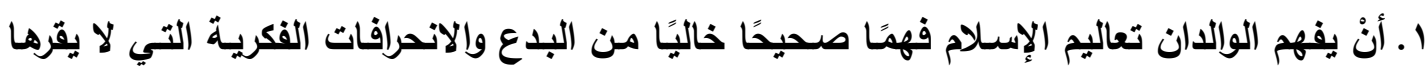

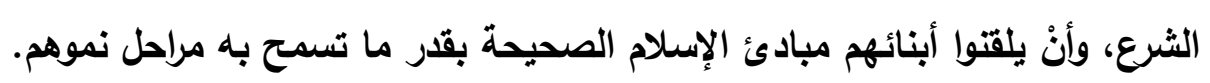

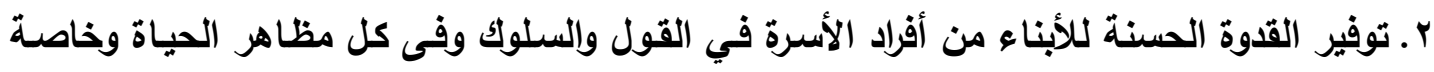
في الجاتب العقلي والفكري. 
r. المتابعة والمراقبة المستمرة لتصرفات الأبناء وسلوكهم، حتى لا يقعوا ضحية المنحرفين من الكبار أو رفاق السوء.

؛. أنْ تستعين الأسـرة بـالبرامج والكتب الموثوق مـن مصـادرها، والتـي تتضـمن المعلومـات الاينيـة والعلمية والثقافية القيمة والمعتبرة في تثثيف وتثنكيل عقل وفكر الأبناء.

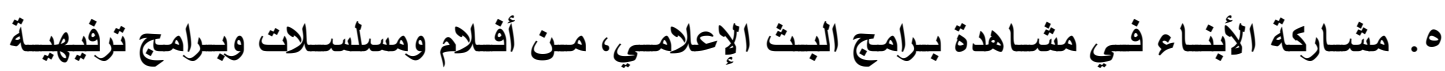
وتعليمية، وذلك بهاف التعرف على ما تحتويه هذه البرامج من أفكار حتى يمكن التوجيه والإرشاد الإدياد

$$
\text { في الوقت المناسب. }
$$

1. توجيه الأبناء لمشـاهدة بعض البرامج، وقراءة بعض الكتب والتي تسـاعد في صقل مواهبهر، وتتمية التفكير الإبداعي لايههم، وصقل عقولههم بما يفيد.

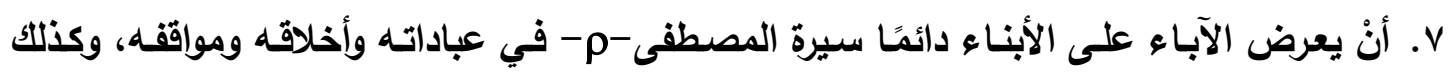

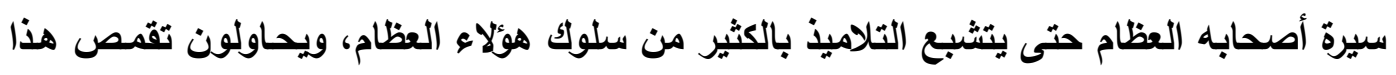
السلوك واكتسابه، ويبتعدوا عن الأفكار المنحرفة. ^. أنْ تهتم الأسرة بتوعيـة الأطفال والتتلاميذ بأهميـة الخير والصـلاح والتمسكك بـائخلاق، وخطورة الثر والفساد. 9 ـ. المتابعة المستمرة للأبناء والاهتمام بهر.

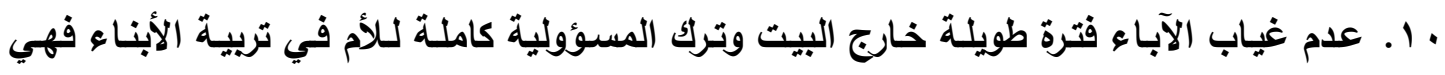

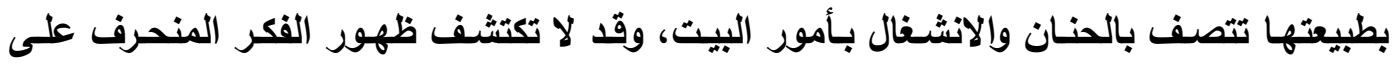

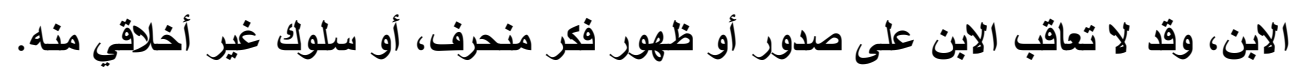

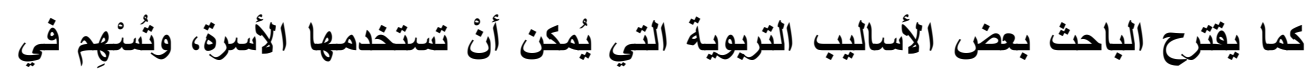
تنشئة أبنائها على الفكر الآمن من أهمها:

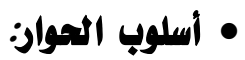

يقوم أسلوب الحوار على مبلأ الثوري أو ما يعرف حديثًا بالايمقرطية، ولذا فهو من أهم

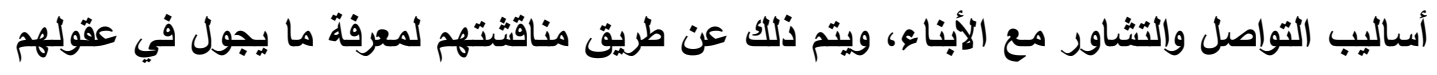

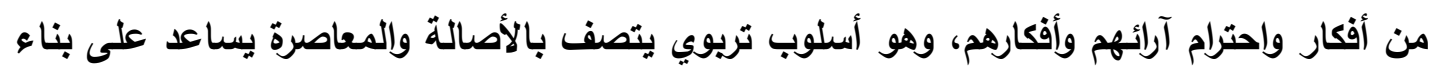

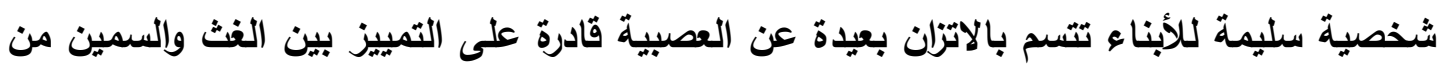

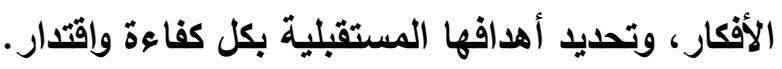

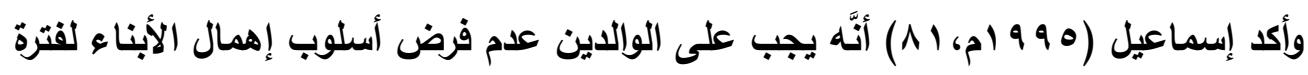

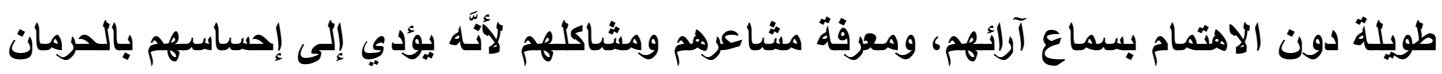

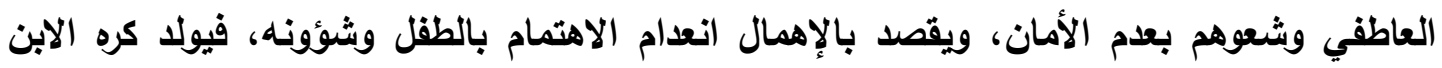


لوالديه فيحدث لايه ردة فعل سلبية بجلب الانتباه عن طريق التخريب أو الانتقام أو القيام بأي سلوك قد يصل إلى إيذاء نفسه لجلب الانتباه إليه من قبل والايه أو أسرتهاه

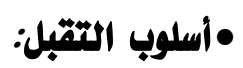

يُعتبر التقبل من الأساليب التربوية الهامة في تنثئة الأبناء على الفكر الآمن الذي يحتاجه

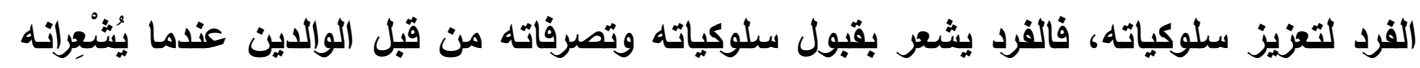

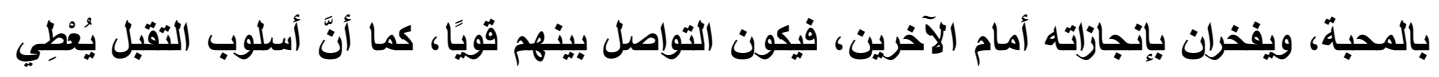

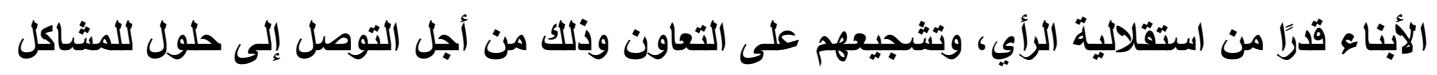

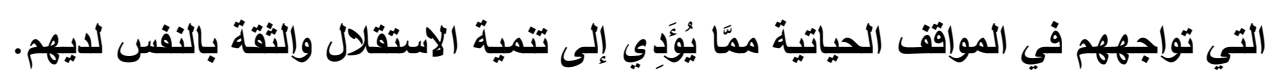

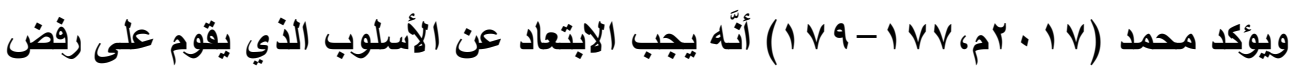

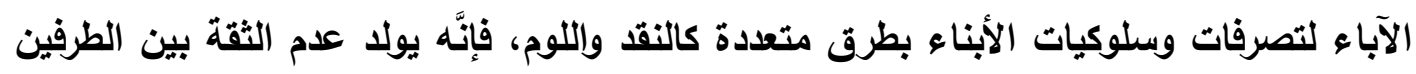

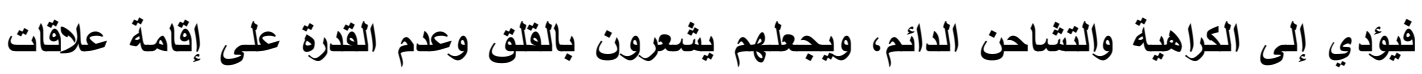

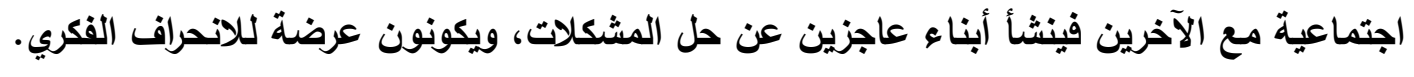

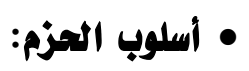

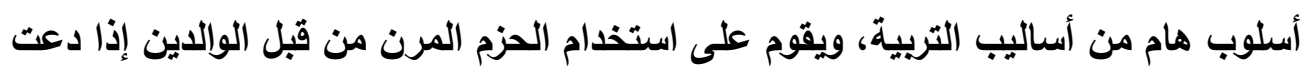

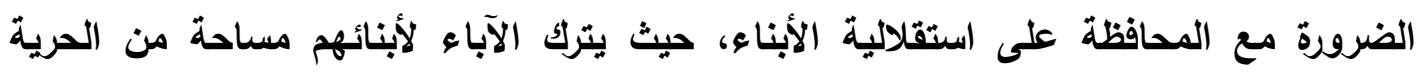

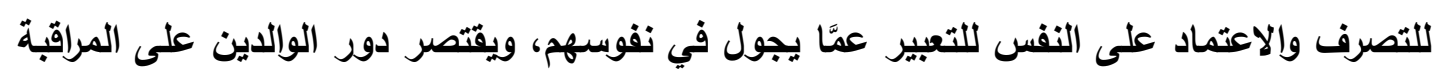

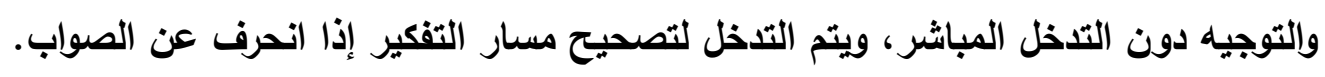

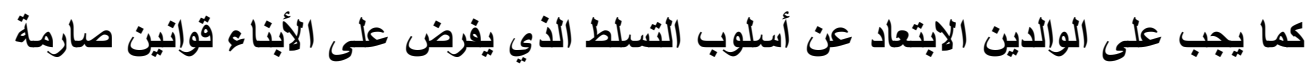

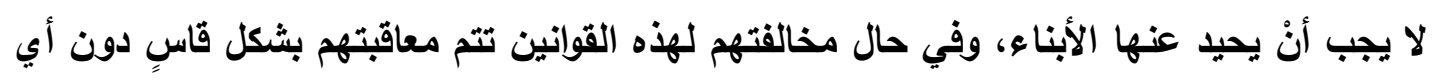

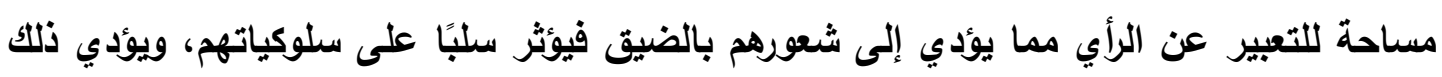

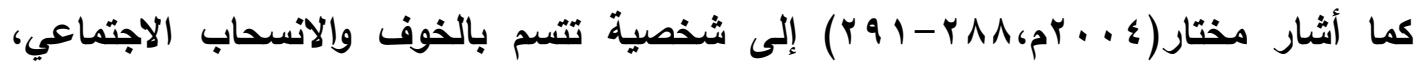

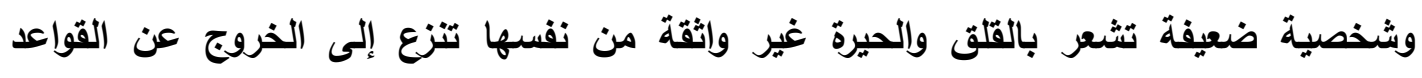

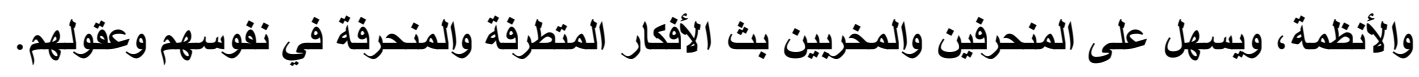

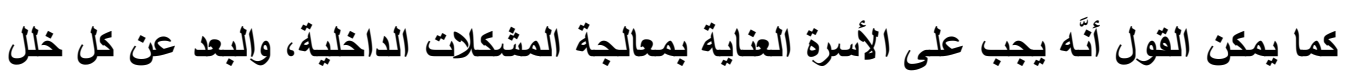

من شأنه التأثير في فكر وسلوك الناشئة.

تقائج البعث:

توصل الباحث من العرض السابق لأدوار ووظائف الأسرة ودورها في تنثئة أبنائها على العنى

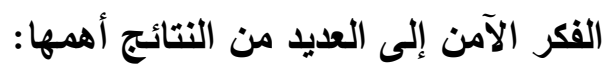
اـ أنَّ الفكر الآمن الصحيح ضرورة ملحة في هذا العصر الكافة أفراد المجتمع. 
r. أنَّ الأبناء إذا صلحوا صلح المجتمع واستقر الأمن.

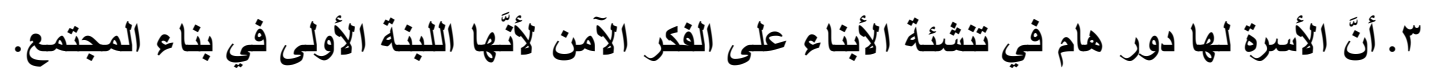

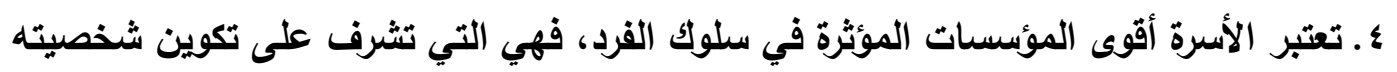

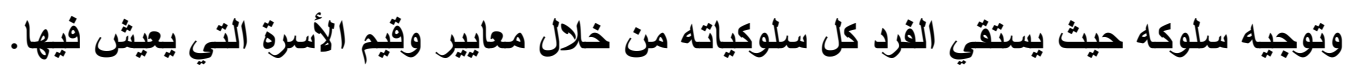

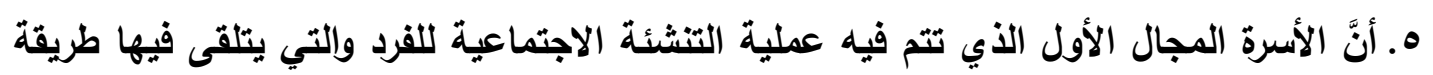

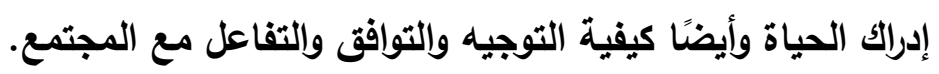

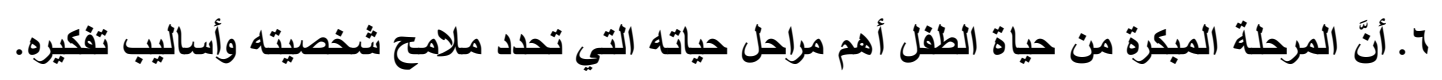

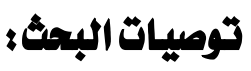

يوصي البحث الحالي الأسرة أنْ تقوم بما يلي:

ا. غرس العقيدة الصحيحة السليمة في نفوس الأبناء، وترسيخ الفكر الآمن الصحيح.

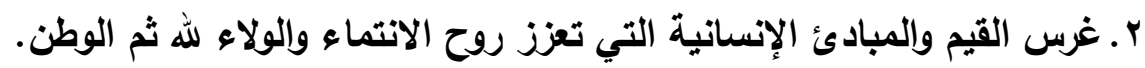

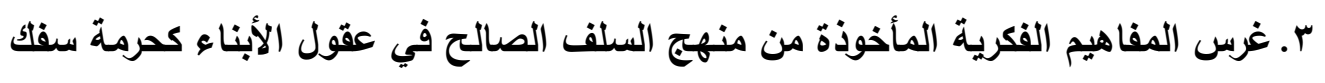

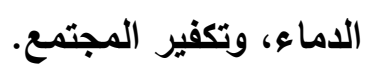

؛ ـ ربط الأبناء بالمناهج الصحيحة التي تقوم على الوسطية والاعتدال.

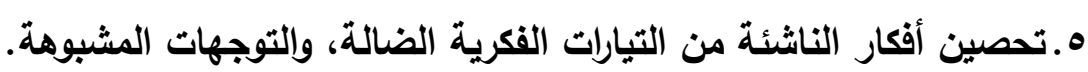

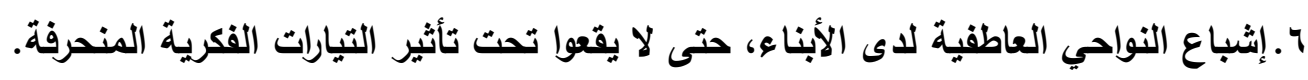

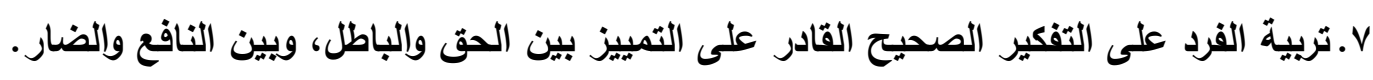

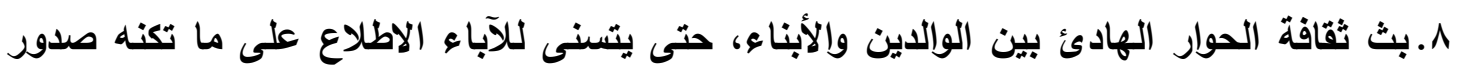
وعقول أبنائهم، فيؤيدون الصحيح ويقومون السقيم.

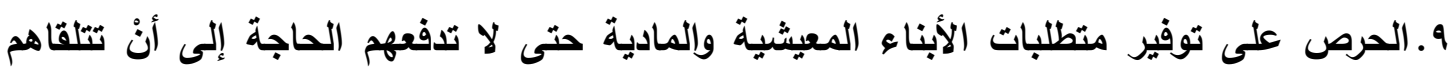

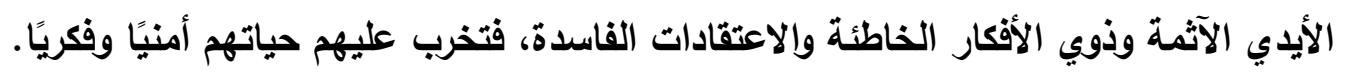

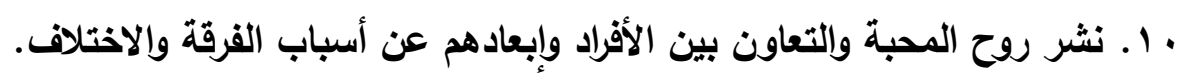
11 1. ترسيخ مبدأ الإحساس بالمسؤولية تجاه أمن الوطن والحفاظ على مقدراته ومكتسباته.

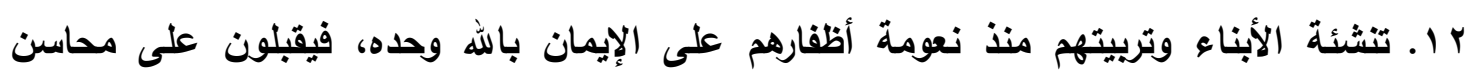

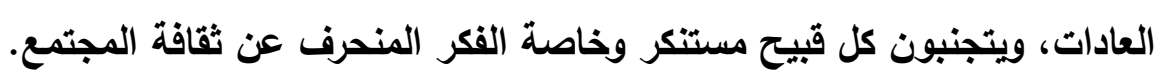
با ا. معرفة أسباب الانحراف الفكري حتى يمكن وضع العلاج المناسب له له. 


\section{المراجع:}

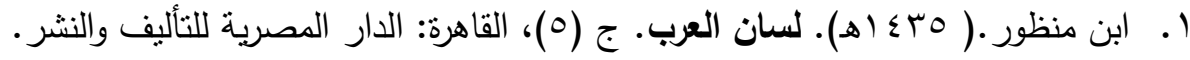
r. أبوالعينين، علي خليل.( • ؟ أهـ). "وسائط تتمية الأخلاق". موسوعة نضرة النعيم في مكارم أخلاق الرسول الكريم، المجلد الأول، جدة: دار الوسيلة للنشر والتوزيع.

r. أبوالعينين، علي خليل.(191 (م). القيم الإسلامية والتربية. المدينة المنورة: مكتبة إبراهيم حلبى.

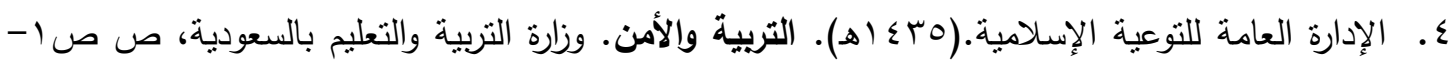

ه. إسماعيل، شعبان محمد.(د.ت). العقيدة الإسلامية وأثرها في تربية الفرد والمجتمع. القاهرة: الهيئة المصرية العامة للكتاب.

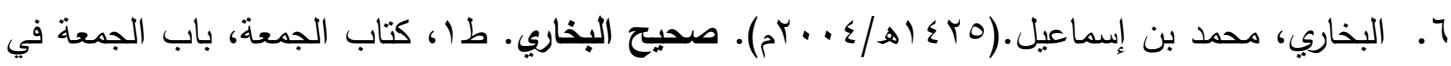
القرى والمدن، ح (ب9))، الرياض: مكتبة الرشد.

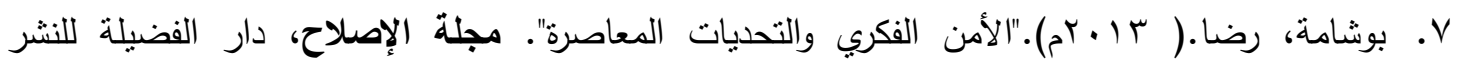

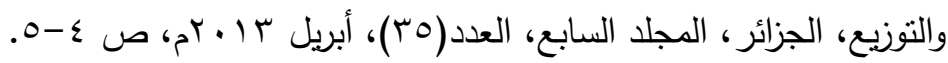

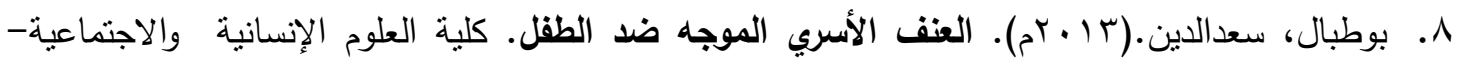

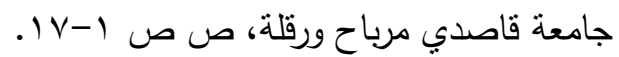

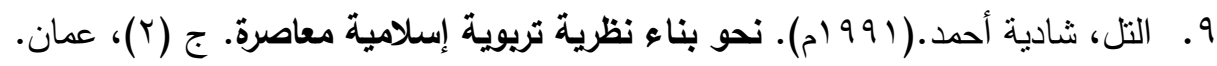

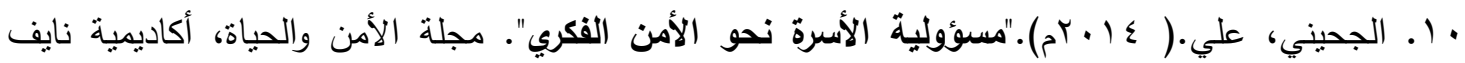

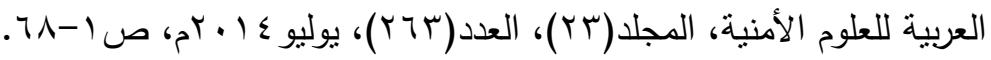

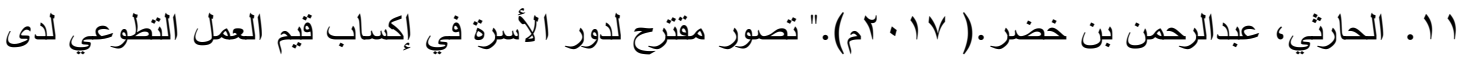
أبنائها من منظور إسلامي". رسالة ماجستير، كلية التربية-جامعة أم القرى. r I. الحاكم.(v . . rم). المستدرك على الصحيحين. ج (ع) ، دار المعرفة، بيروت.

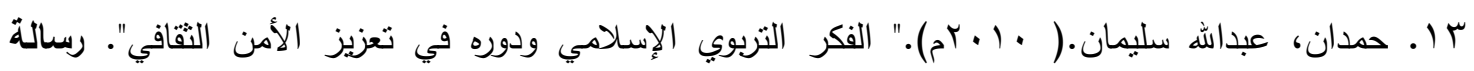
دكتوراه، كلية التربية، جامعة اليرموك - الأردن.

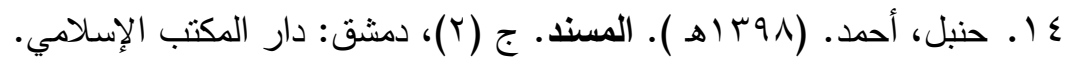

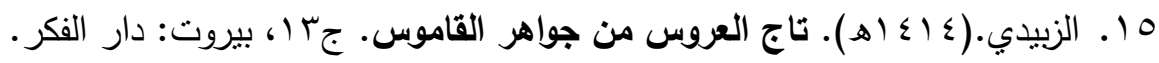

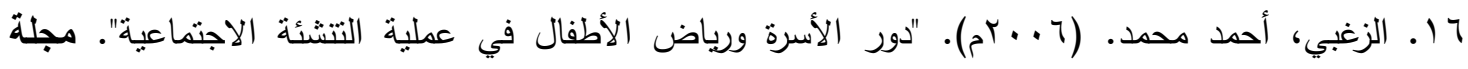

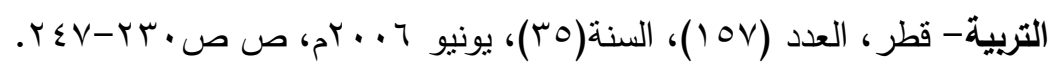

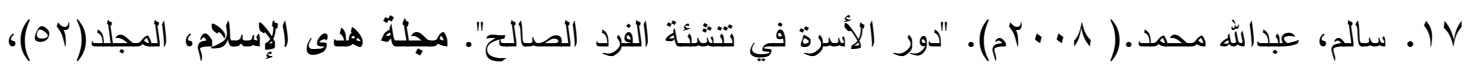

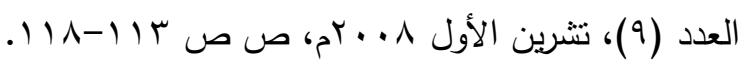


1 ا. السدحان، عبد الله الناصر .(V) إه ). رعاية الأطفال المنحرفين في المملكة العربية السعودية. الرياض: مكتبة العبيكان.

9 1. السعيدي، تيسير حسين.(0 . . rهـ). دور المؤسسات التربوية في الوقاية من الفكر المنطرف. مجلة البحوث

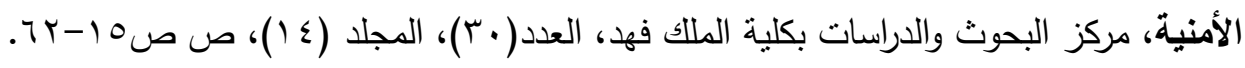

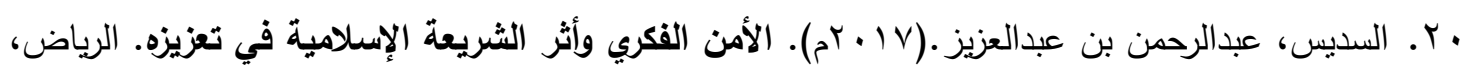

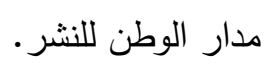

اY. سليمان، عبدالرحمن.( 0 • rم). الأمن الفكري: مستويات التفكير واتجاهات التطبيق. مجلة فكر، مركز

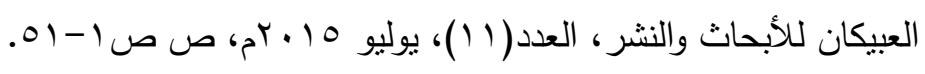

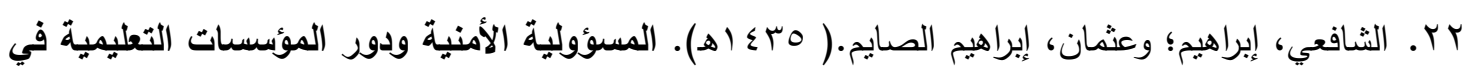

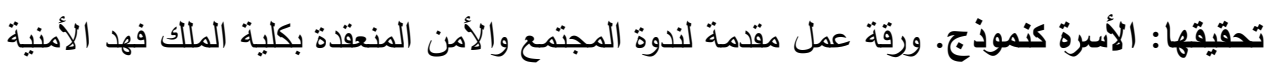

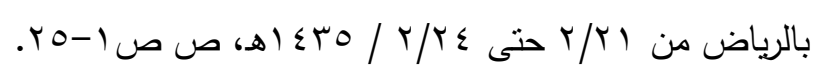

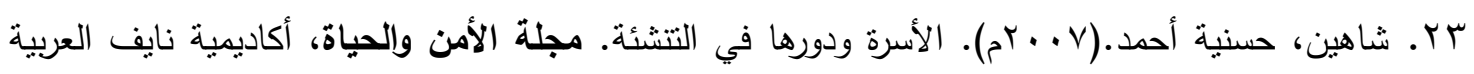

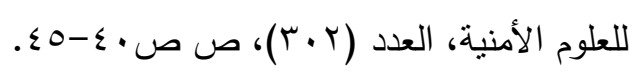

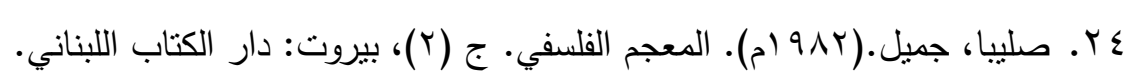

هץ. عبد الله محمد جلال.(ع 99 (م). "بعض العوامل الاجتماعية والاقتصادية المؤثرة على التربية الأخلاقية

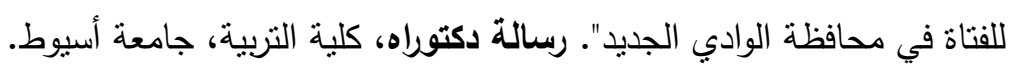

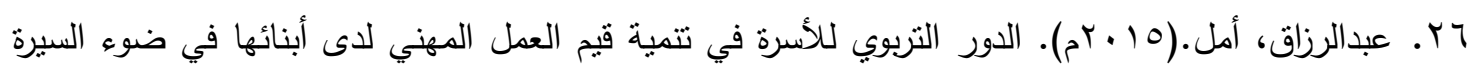

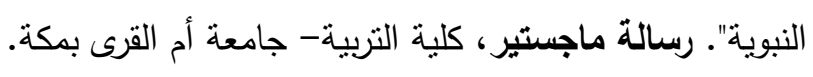

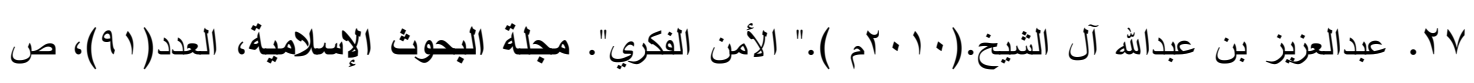

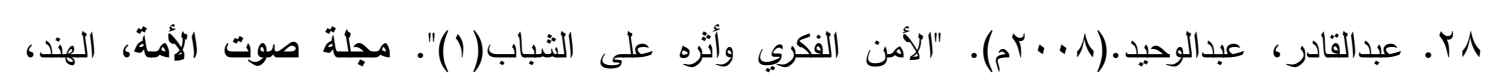

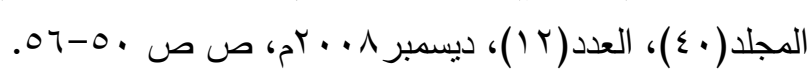

q

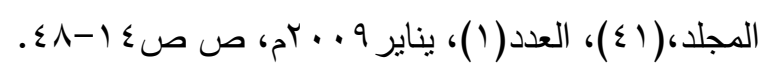

•r. عبدالمطلب، محمد سند.(r • . rم).الأسرة ودورها في الوقاية من الانحراف. مجلة الأمن وإلحياة، أكاديمية نايف.

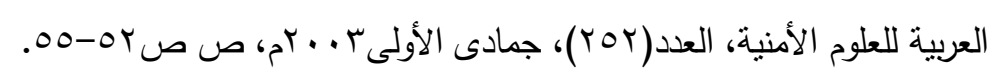

اب. عبدالمطلب،أحمد محمود.(0 . . Yم). التربية الإسلامية بين الواقع والمأمول. كلية التربية بسوهاج.

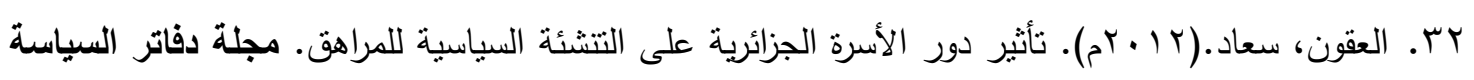

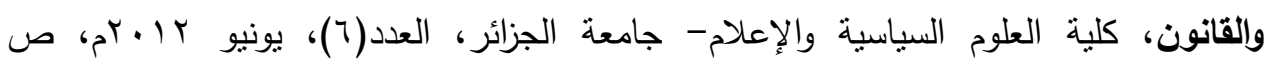

$$
\text { ص }
$$

سب. علوان، عبداله ناصح.(990 (م). تربية الأولاد في الإسلام. القاهرة: دار السلام للطباعة والنشر. 


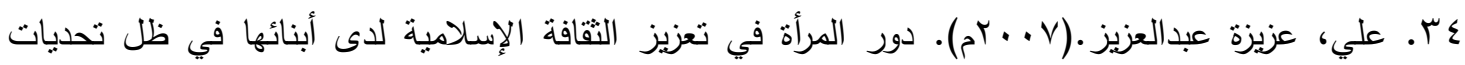

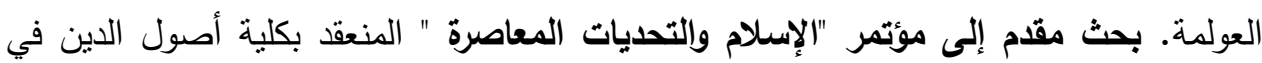

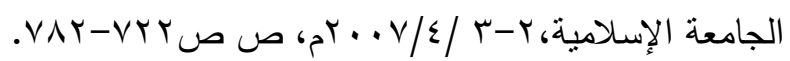

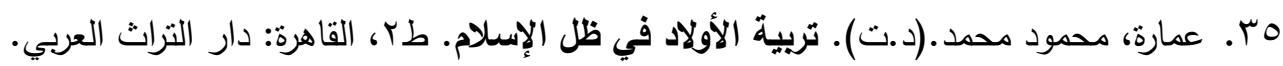

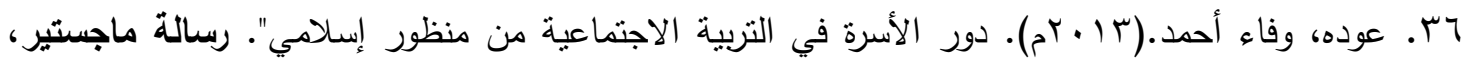

$$
\text { كلية الثريعة والدراسات الإسلامية- جامعة تنوك - الأردن. }
$$

VT. الغزالي، محمد بن محمد.(د.ت). إحياء علوم الاين. ج (r)، بيروت: دار الكتب العلمبة.

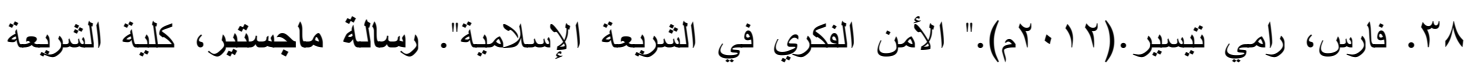
والقانون - الجامعة الإسلامية بغزة - فلسطين.

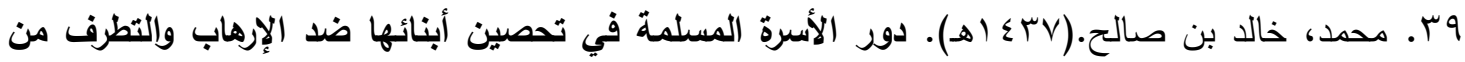

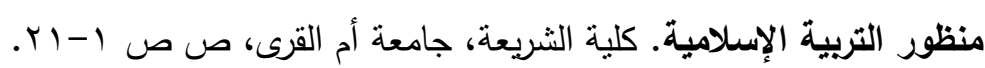

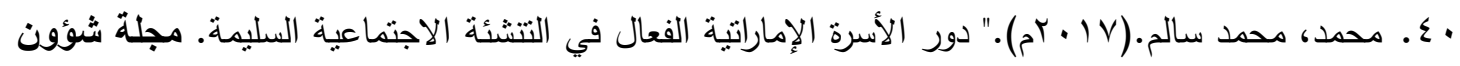

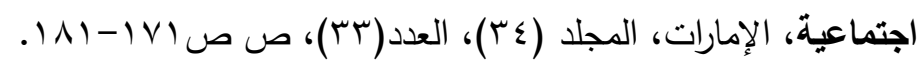

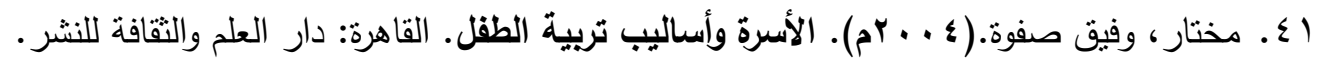
Yع. نظمى، رانيا محمد عزيز .( هب؟ (هـ). دور الأسرة في تفعيل الوسطية لبناء المناعة الفكرية لدى الأبناء.

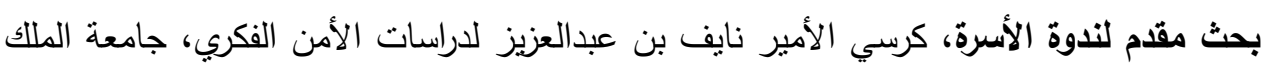

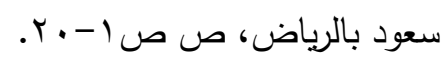

بــ الهذيلي، ماجد بن محمد.(س (هـ). "مفهوم الأمن الفكري دراسة تأصيلية في ضوء الإسلام". رسالة

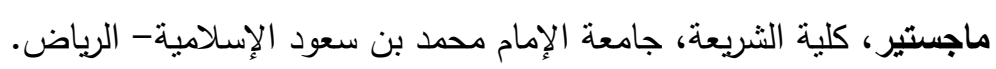

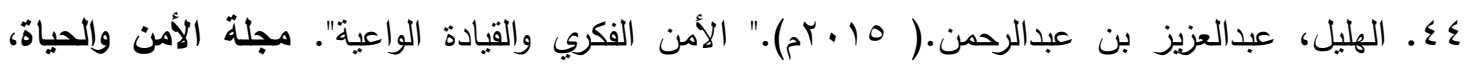

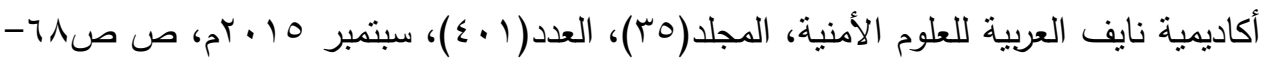

$$
\text { . V. }
$$

45. Bullock, ( J,18,1988 )The relationship between parent $\mathbf{s}$ perception of the family Environment and children s. Child Study.

46. William M. Pinsof \& Jay L. Lebow (2005). Family Psychology: The Art of the Science. New York: Oxford University Press.

47. Juliet Sharman-Burke (2007). The Family Inheritance: Parental Images in the Horoscope. New York: CPA Press.

48. Rudi Dallos \& Ros Draper (2015). An Introduction to Family Therapy: Systemic Theory and Practice. London: Open University Press.

49. Defrain, John, et al. (2008), "Creating a strong family." are families so important, international journal, VOL(31,NO97,PP351-352.

50. Brigitte Berger, University, Wellesley College, and Boston University ,Publisher: Transaction Publishers (June 18, 2002) ISBN-13: 9780765801210. 